\title{
An Upstream Battle: The EU and the Reform of the Energy Charter Treaty
}

Citation for published version (APA):

Herranz-Surrallés, A. (2016). An Upstream Battle: The EU and the Reform of the Energy Charter Treaty. In E. Barbé, O. Costa, \& R. Kissack (Eds.), EU Policy Responses to a Shifting Multilateral System (pp. 4969). Palgrave Macmillan. The European Union in International Affairs https://doi.org/10.1057/978-1-13754758-3_3

Document status and date:

Published: 01/01/2016

DOI:

10.1057/978-1-137-54758-3_3

Document Version:

Publisher's PDF, also known as Version of record

Document license:

Taverne

Please check the document version of this publication:

- A submitted manuscript is the version of the article upon submission and before peer-review. There can be important differences between the submitted version and the official published version of record.

People interested in the research are advised to contact the author for the final version of the publication, or visit the DOI to the publisher's website.

- The final author version and the galley proof are versions of the publication after peer review.

- The final published version features the final layout of the paper including the volume, issue and page numbers.

Link to publication

\footnotetext{
General rights rights.

- You may freely distribute the URL identifying the publication in the public portal. please follow below link for the End User Agreement:

www.umlib.nl/taverne-license

Take down policy

If you believe that this document breaches copyright please contact us at:

repository@maastrichtuniversity.nl

providing details and we will investigate your claim.
}

Copyright and moral rights for the publications made accessible in the public portal are retained by the authors and/or other copyright owners and it is a condition of accessing publications that users recognise and abide by the legal requirements associated with these

- Users may download and print one copy of any publication from the public portal for the purpose of private study or research.

- You may not further distribute the material or use it for any profit-making activity or commercial gain

If the publication is distributed under the terms of Article $25 \mathrm{fa}$ of the Dutch Copyright Act, indicated by the "Taverne" license above, 
See discussions, stats, and author profiles for this publication at: https://www.researchgate.net/publication/309078690

\section{An Upstream Battle: The EU and the Reform of the Energy Charter Treaty}

Chapter · January 2016

DOI: 10.1057/978-1-137-54758-3_3

\section{CITATIONS}

4

1 author:

Anna Herranz-Surralles

Maastricht University

44 PUBLICATIONS 574 CITATIONS

SEE PROFILE

Some of the authors of this publication are also working on these related projects:

Project $\quad$ EU-NormCon (Normative contestation in Europe: Implications for the EU in a changing global order) View project

Project Grup de Recerca Consolidada “Observatorio de Política Exterior Europea” View project
READS

123 


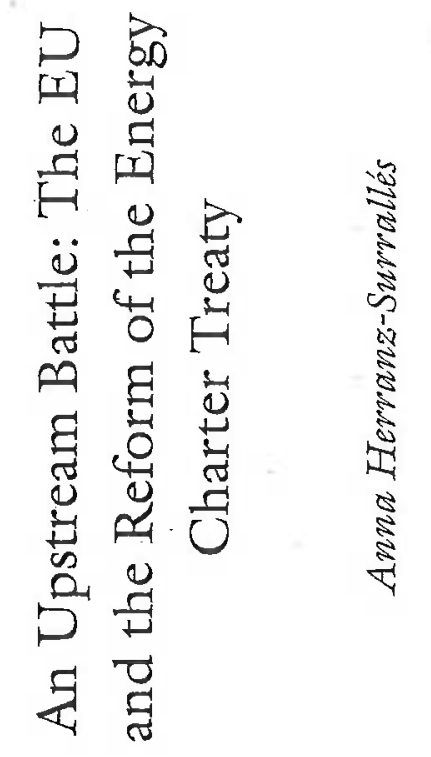

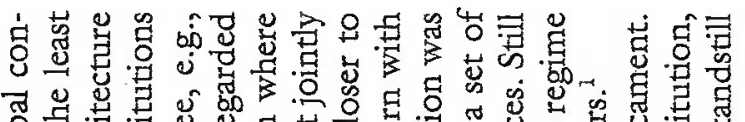

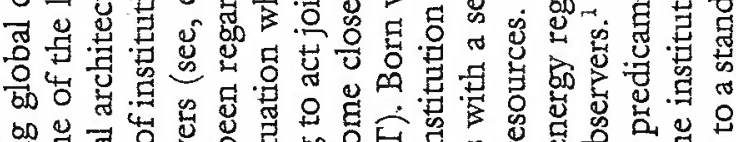

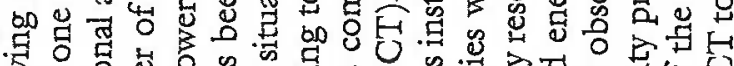

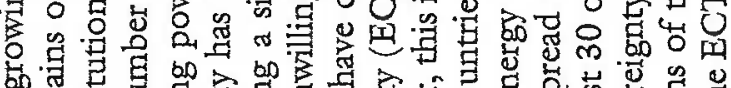

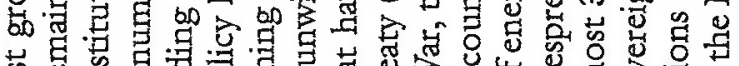

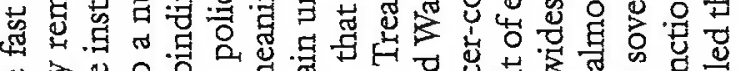

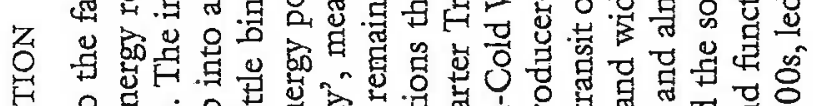

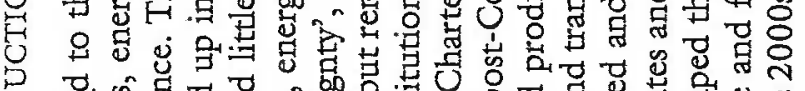

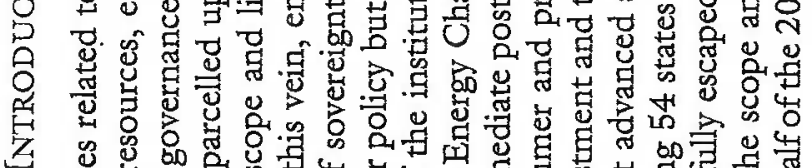

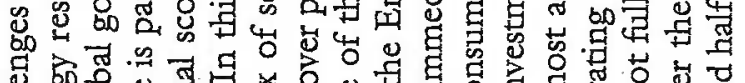

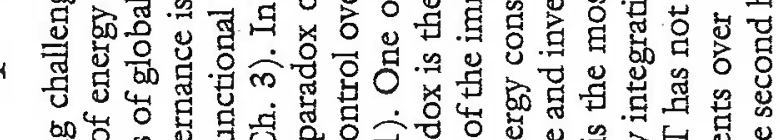

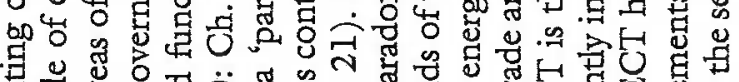

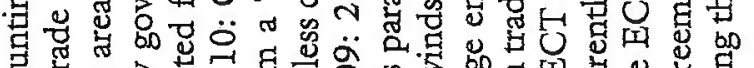

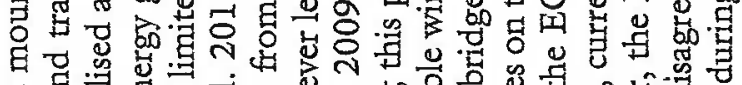

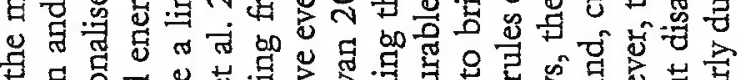

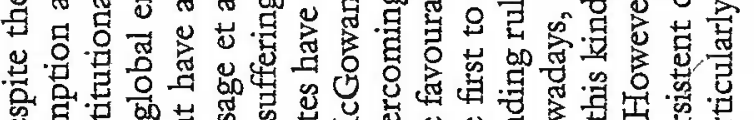

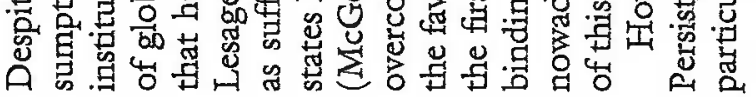
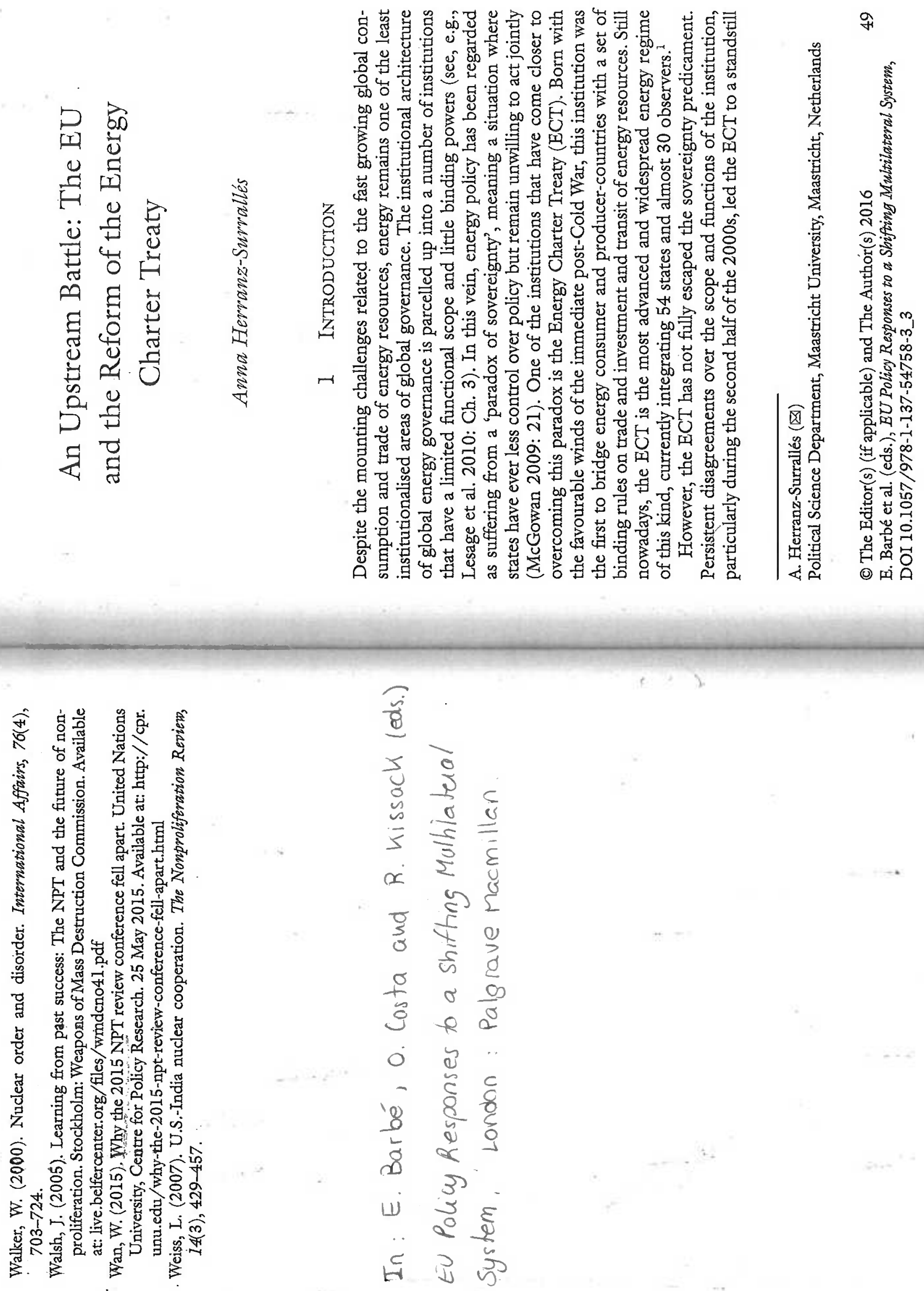


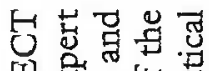
口

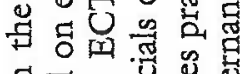

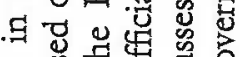
$\because \%$

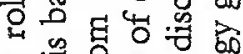

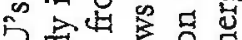

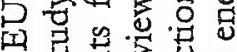

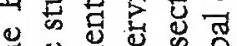

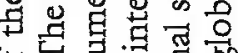

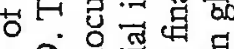

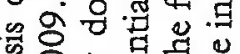
究운

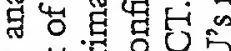

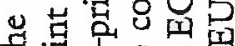
के

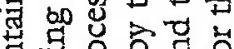

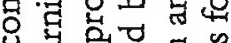
当

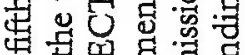
담

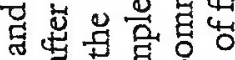

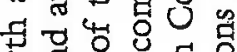

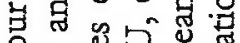

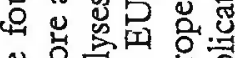

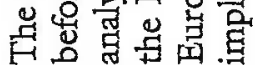

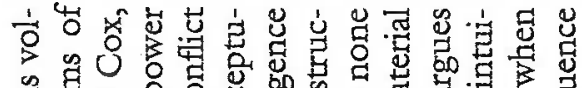

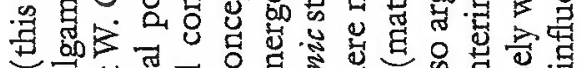

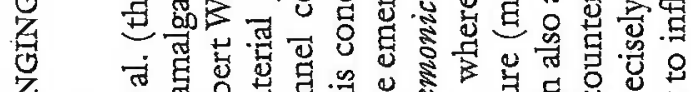

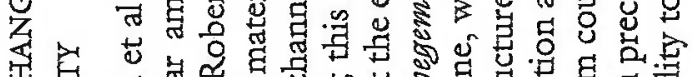
出 牙出当

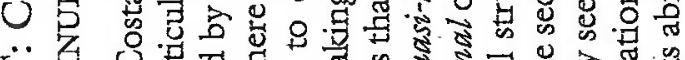

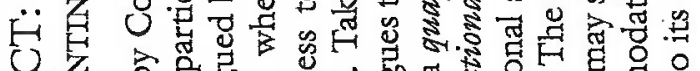

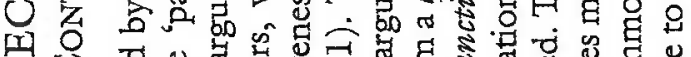

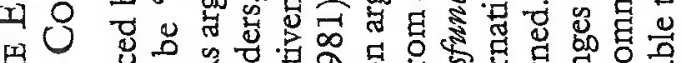

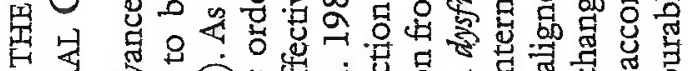

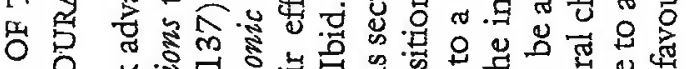

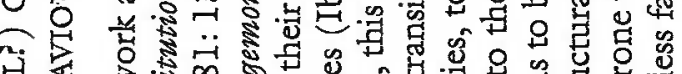
空

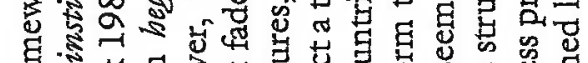

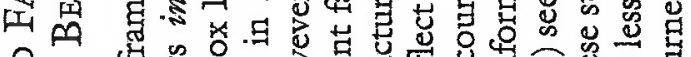

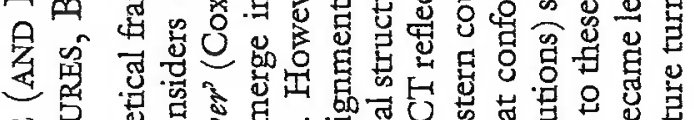

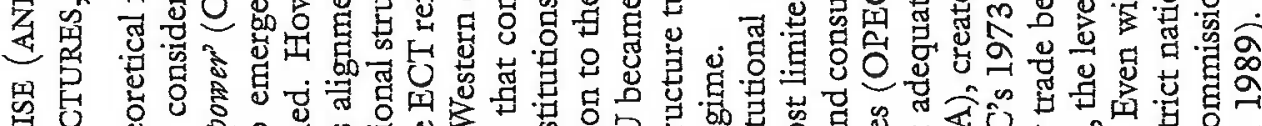

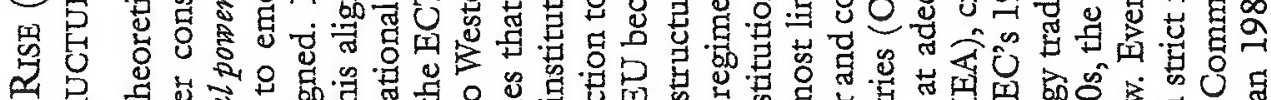

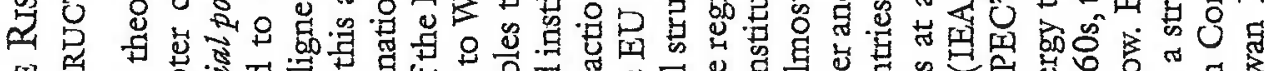

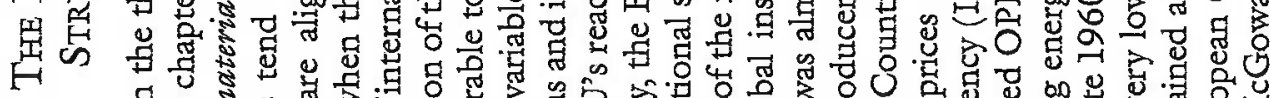
5.

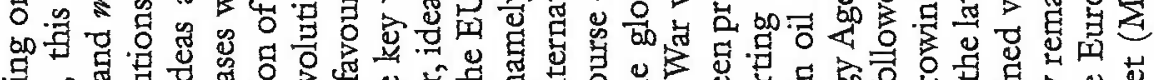

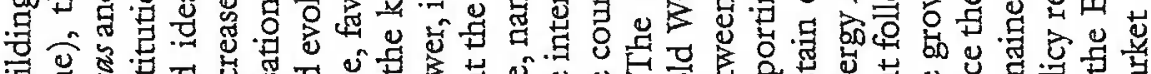

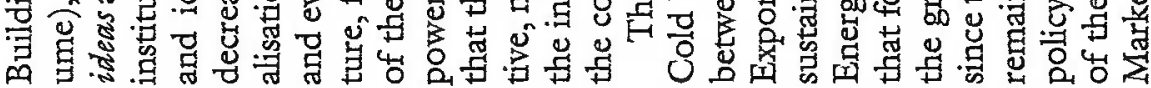

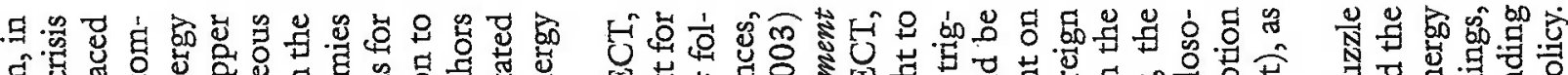

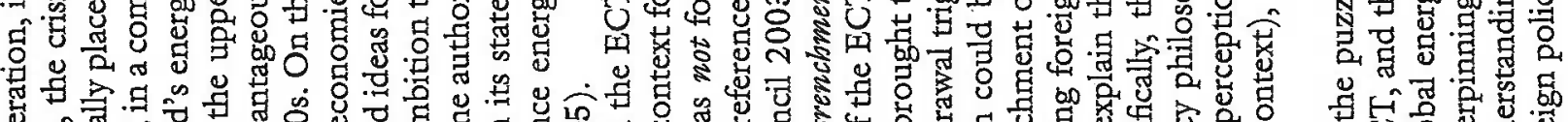

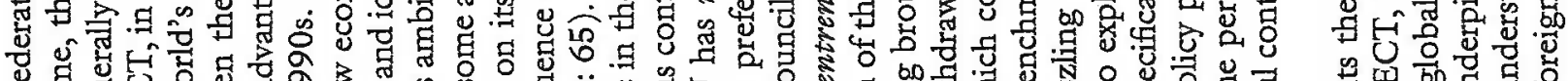

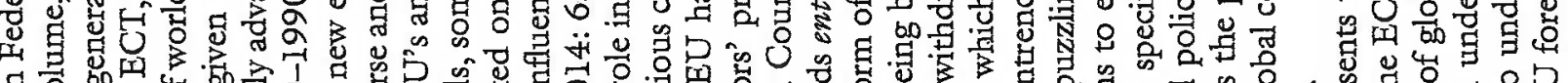

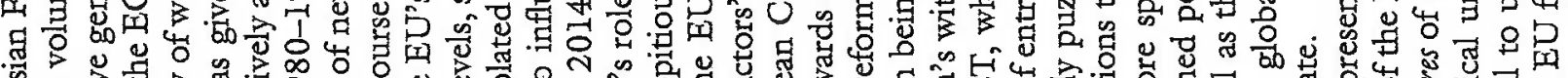

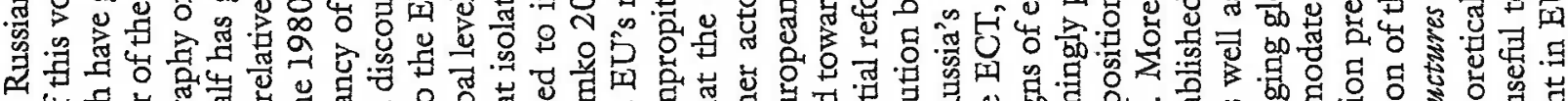

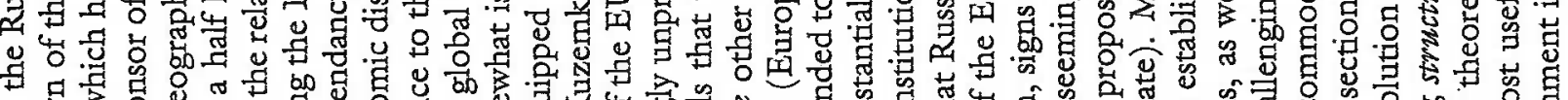

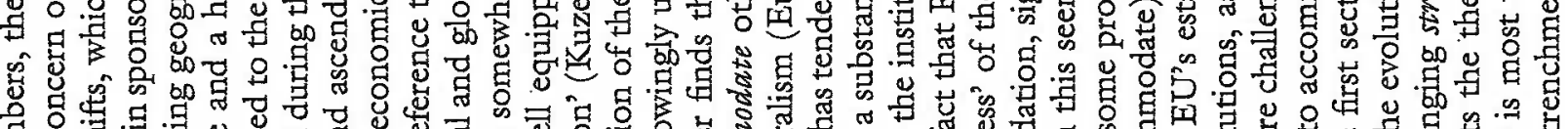

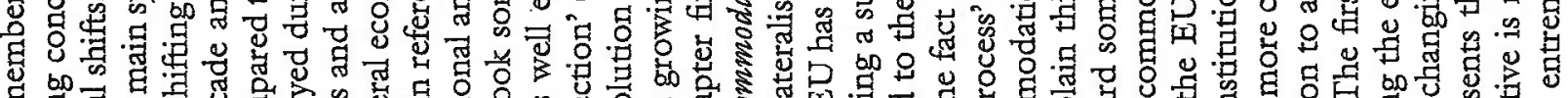

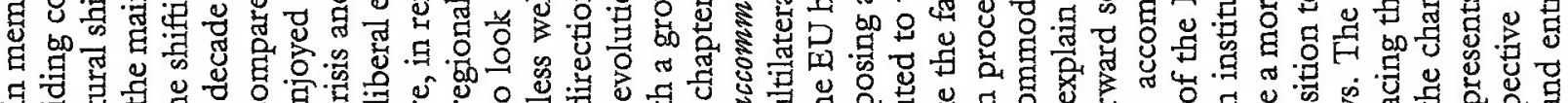

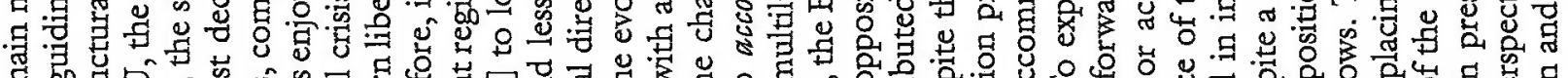

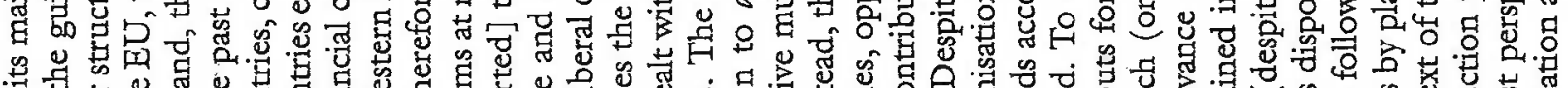

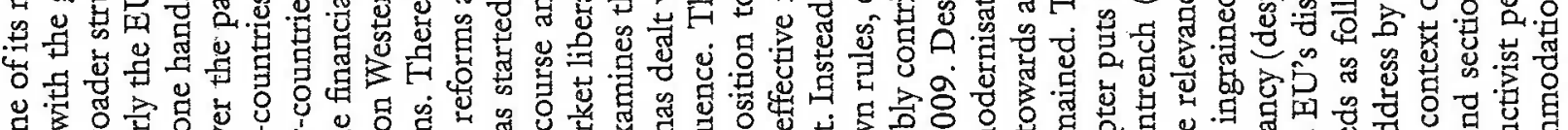

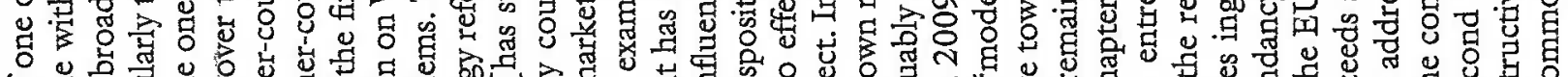

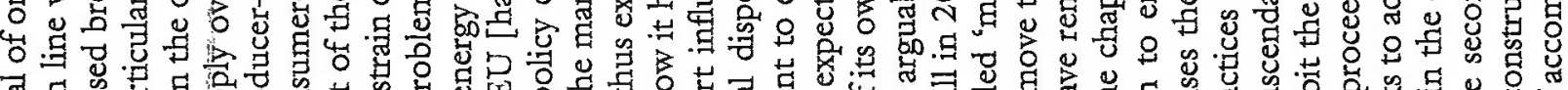

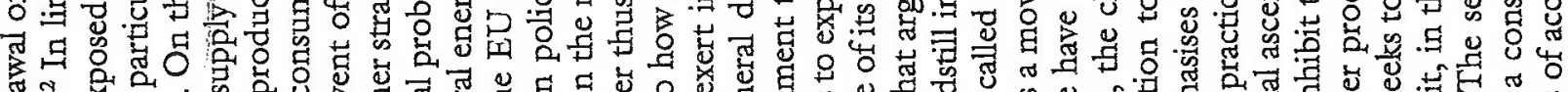

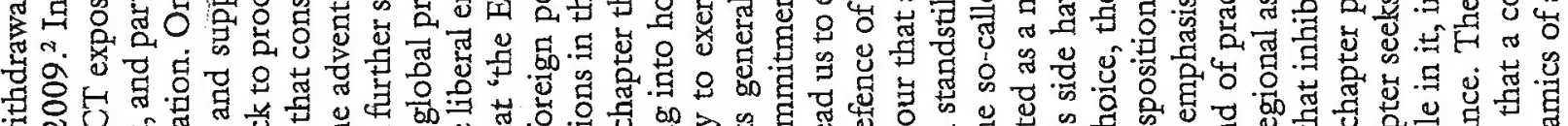

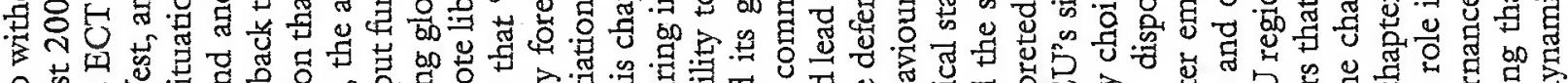

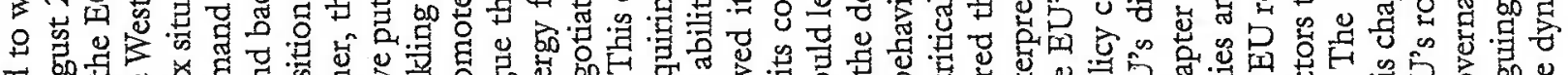

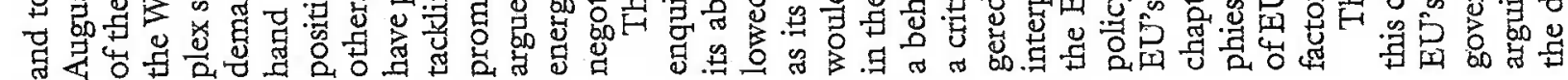




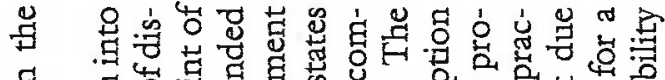

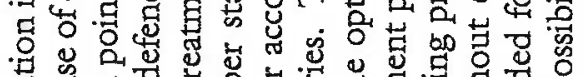

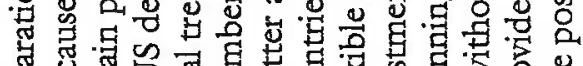

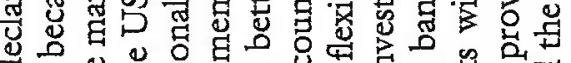

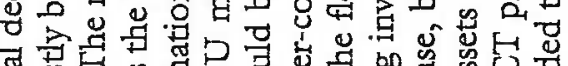

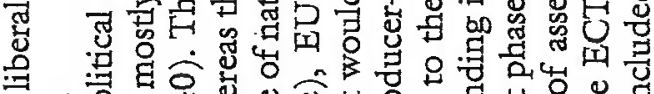

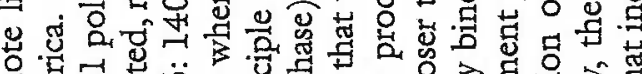

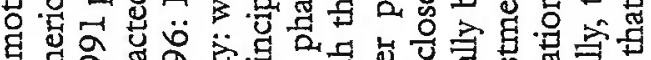

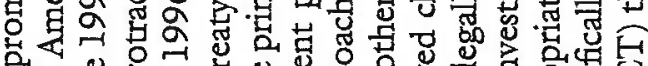

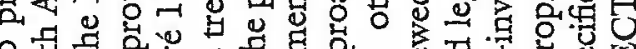

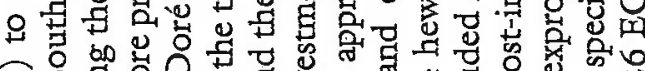

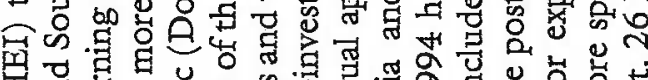

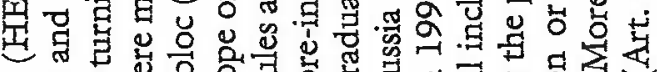

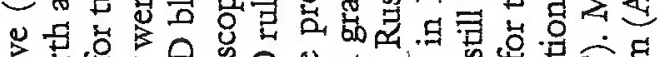

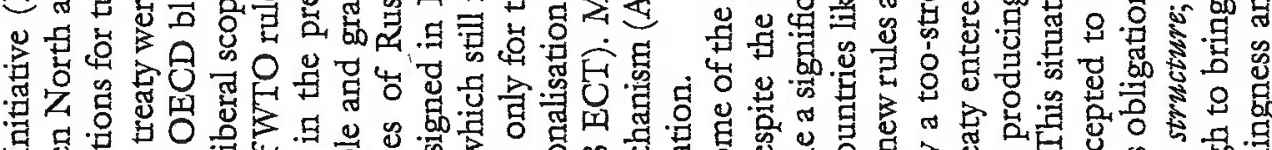

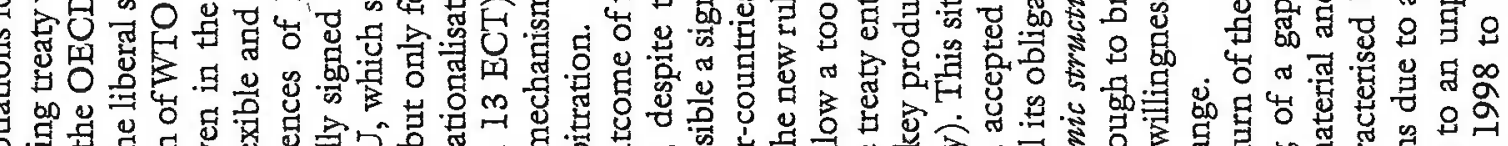

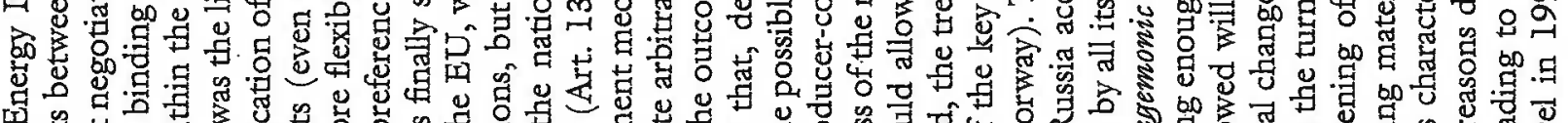

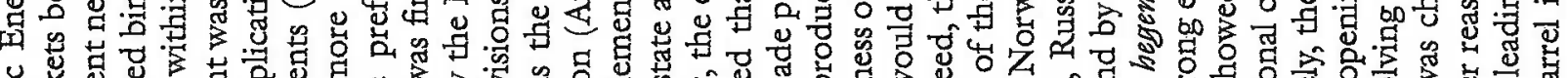

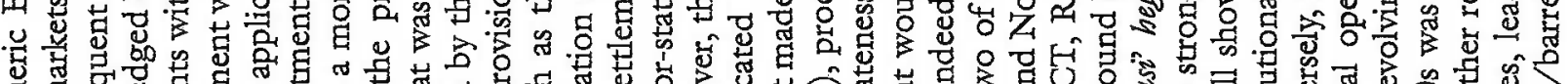

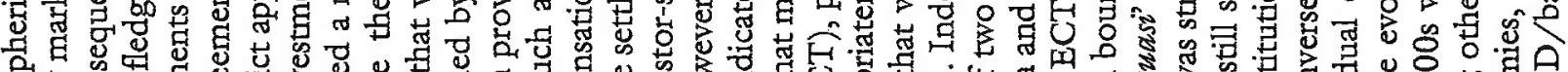

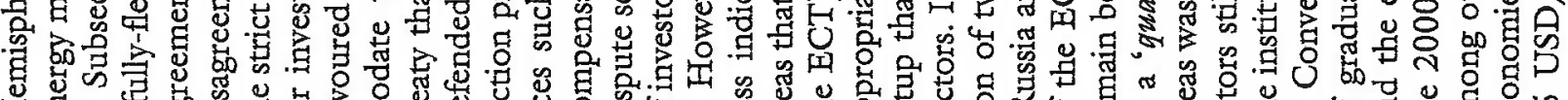

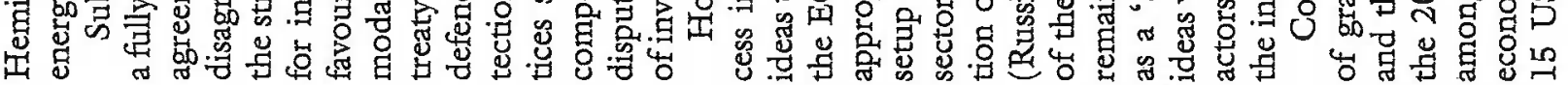

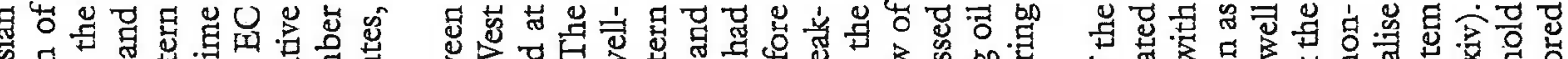

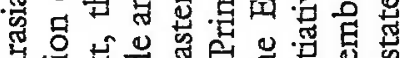

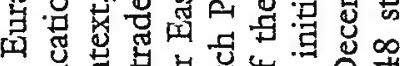

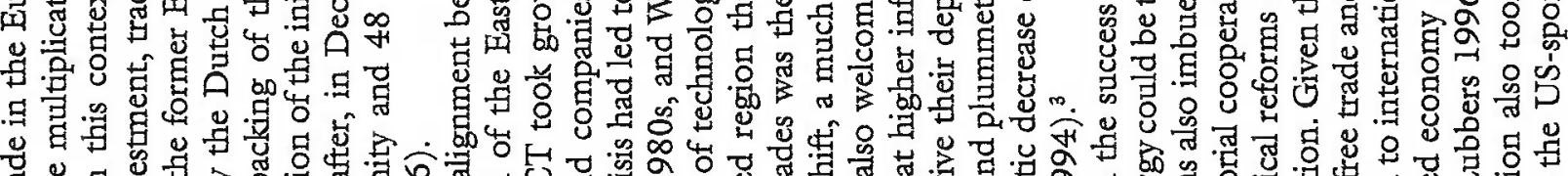

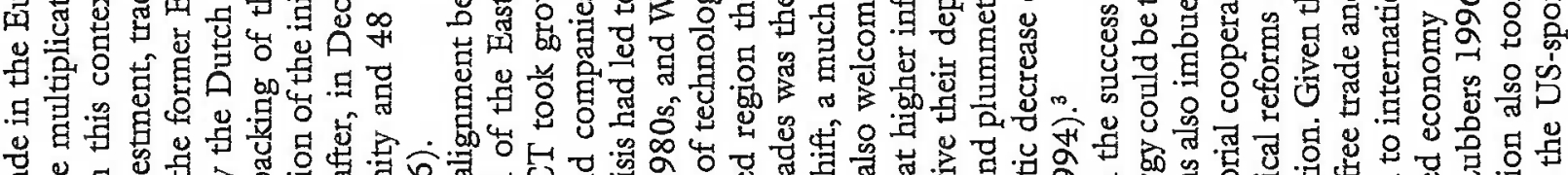

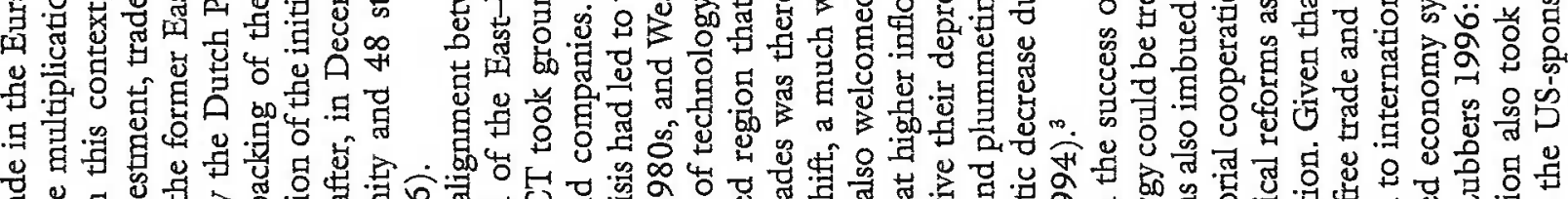

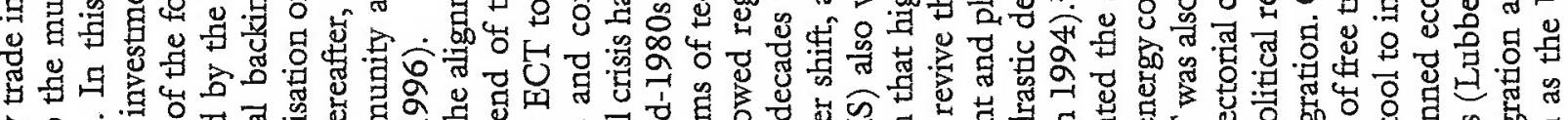
耳

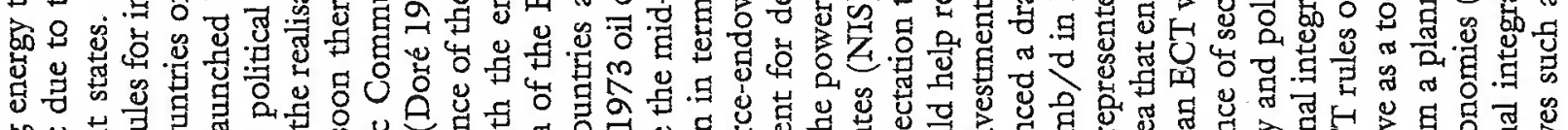

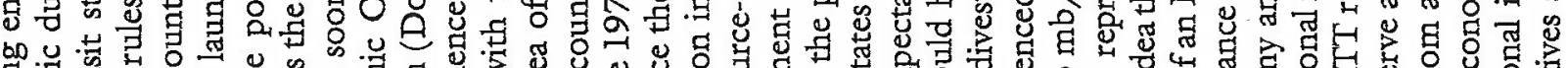

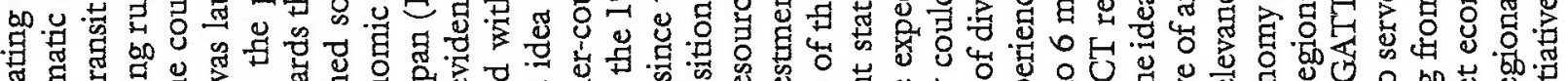

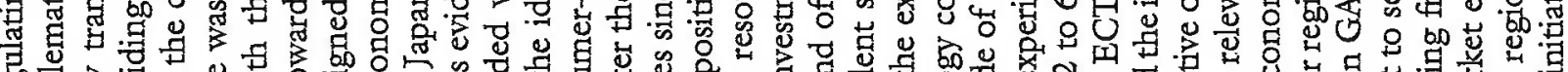

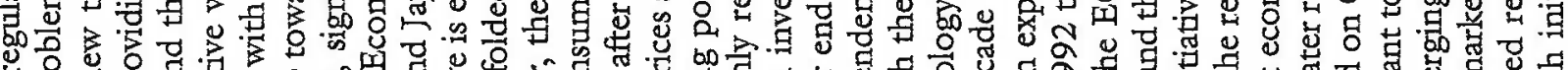

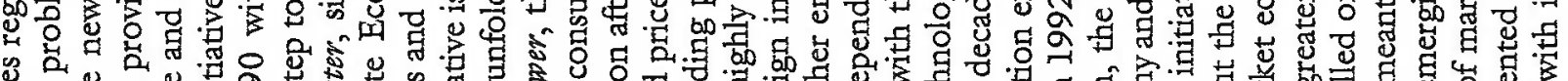

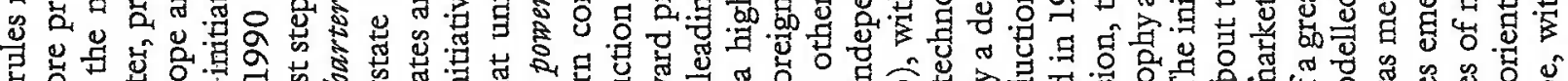

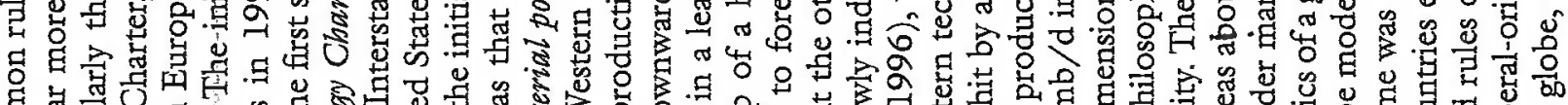
E

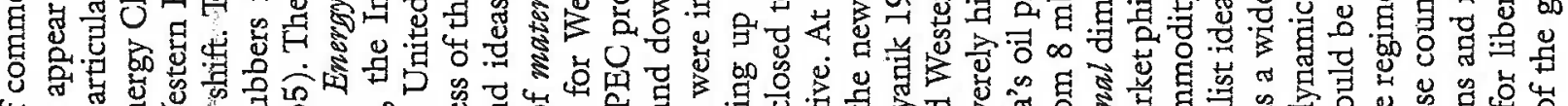

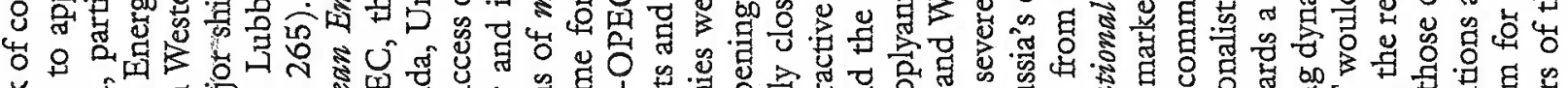

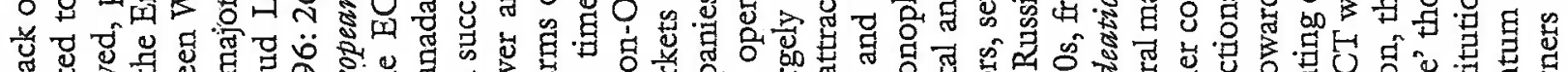

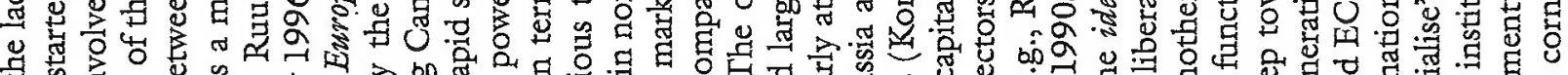

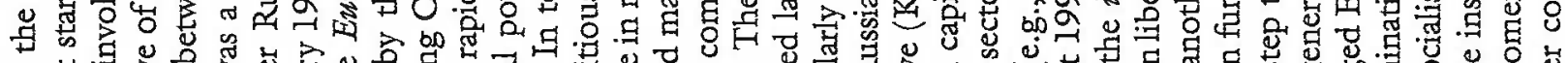

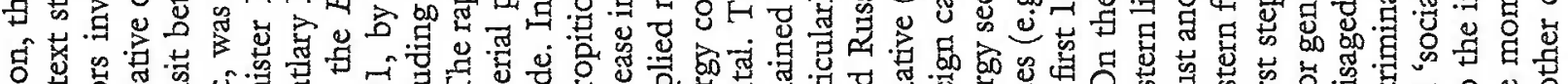

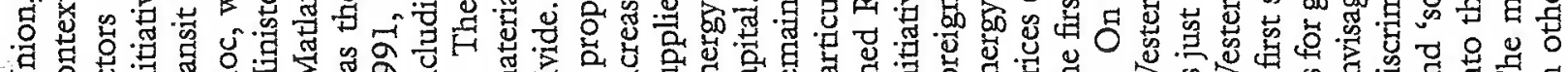
พ 

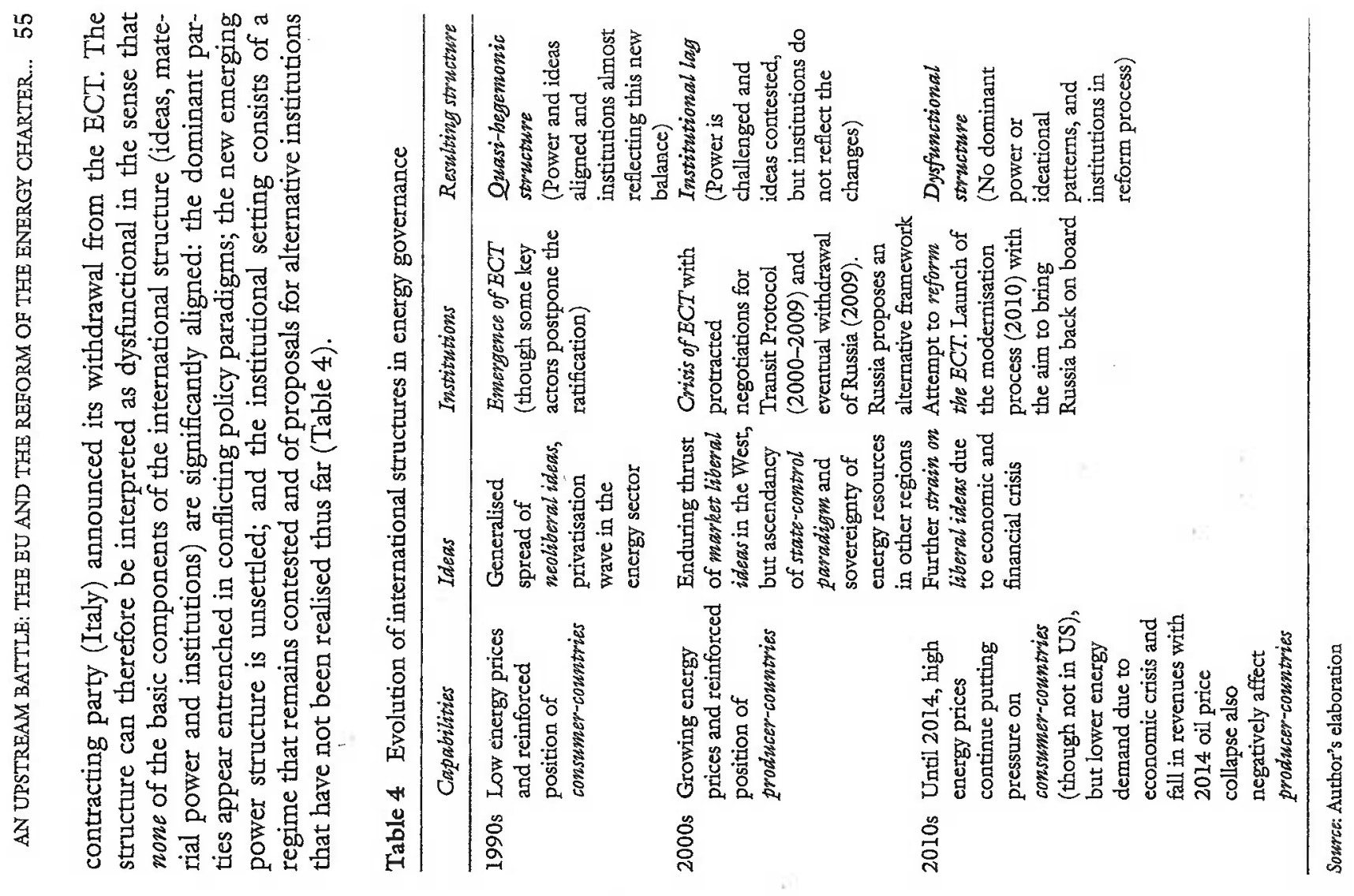

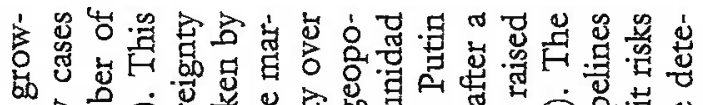

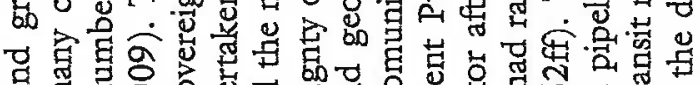

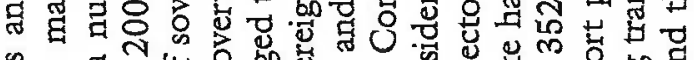
.

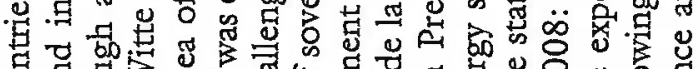

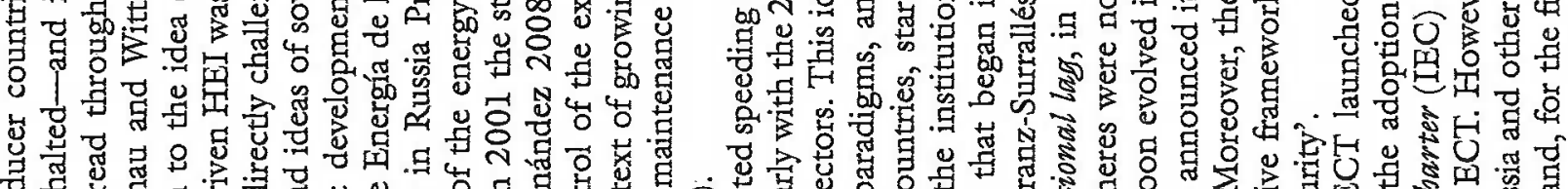

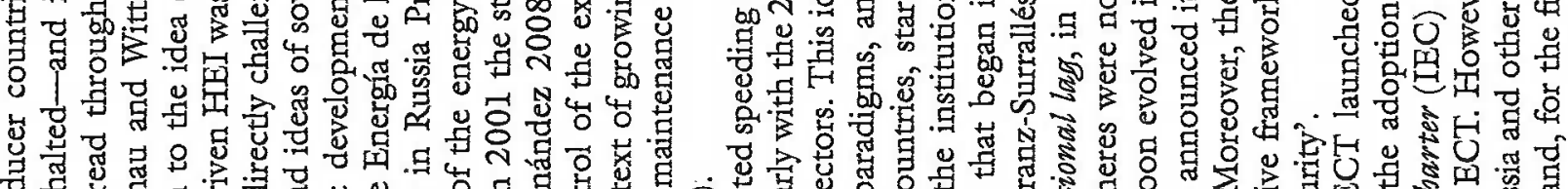

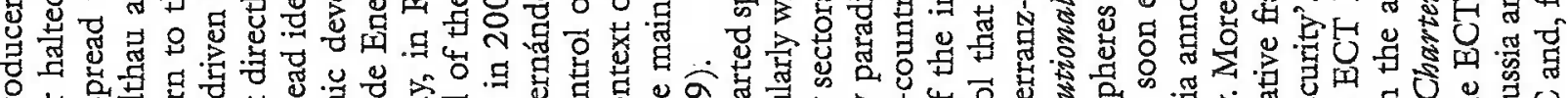

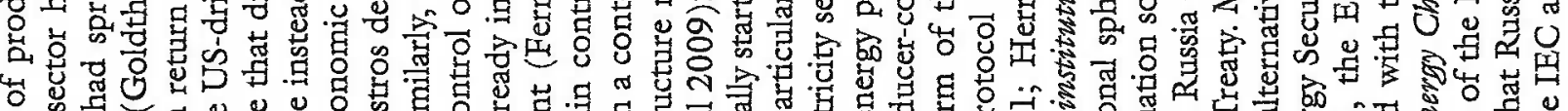

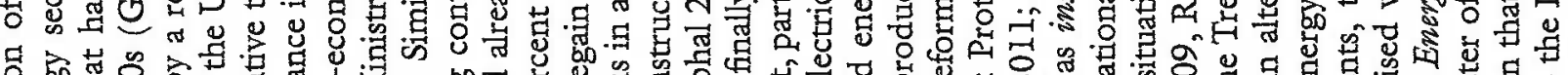

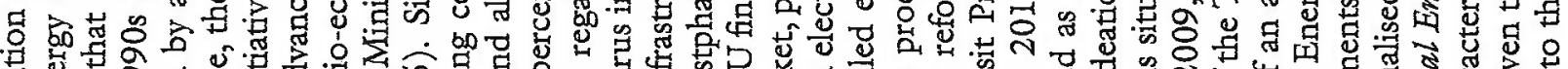

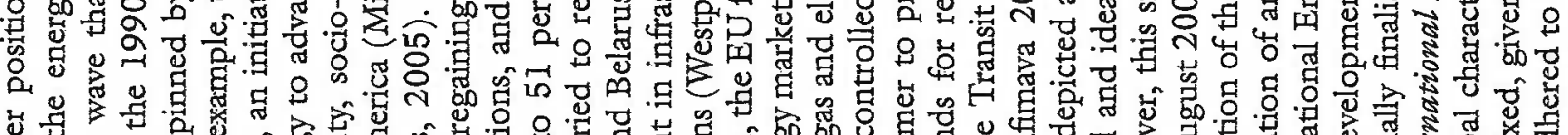

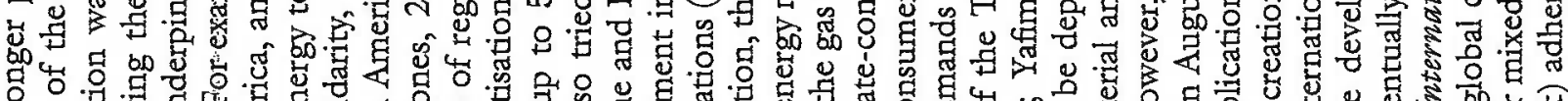

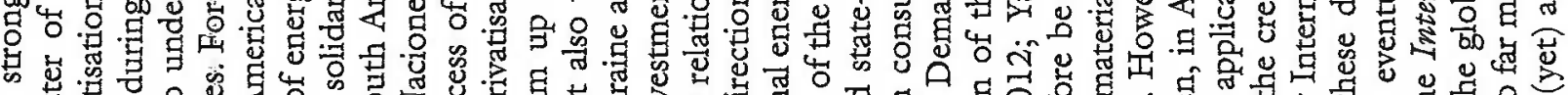

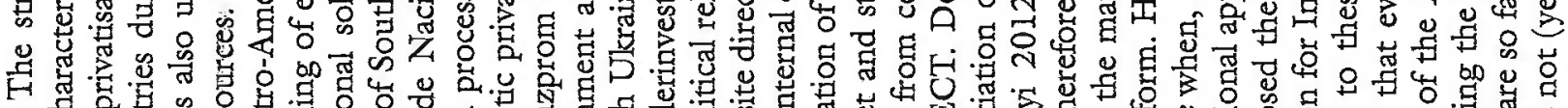

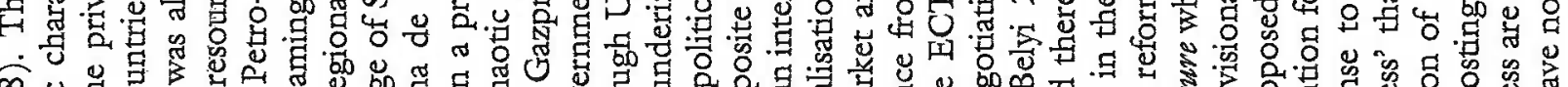

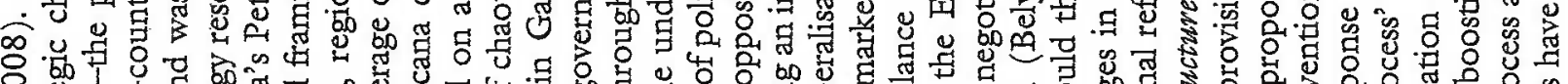

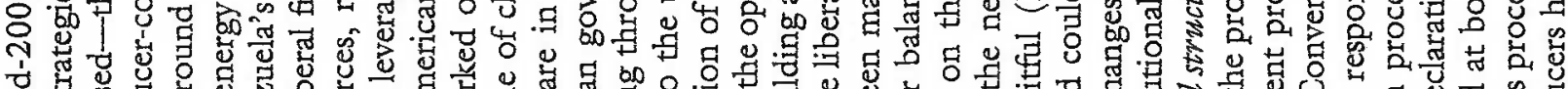

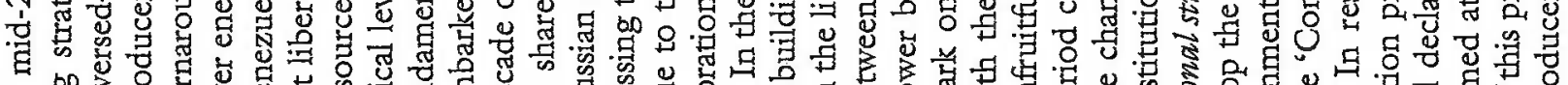

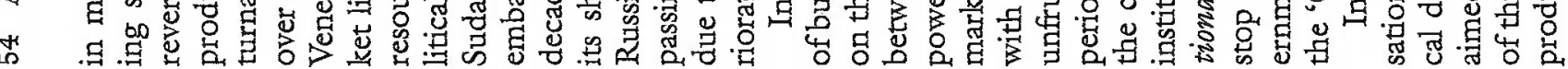




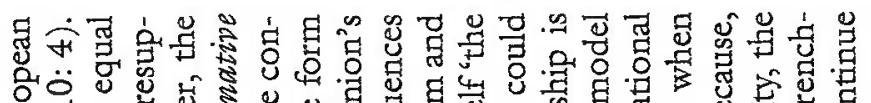

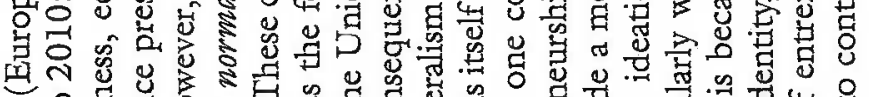

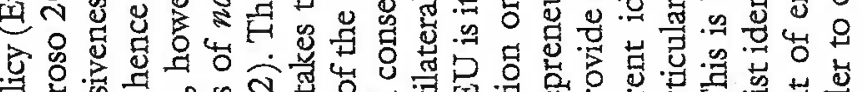

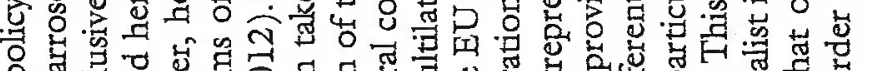

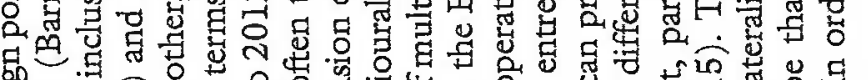
品.

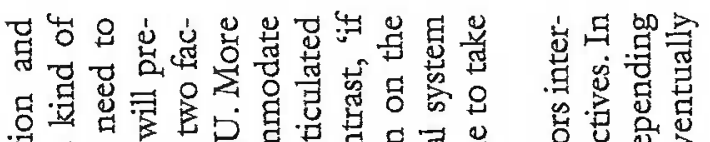

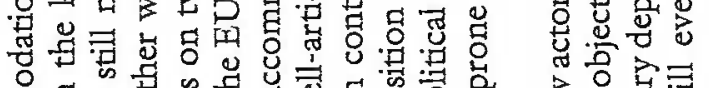
要

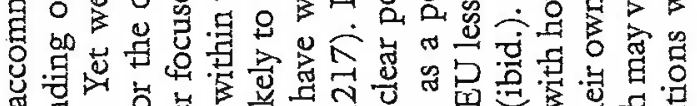

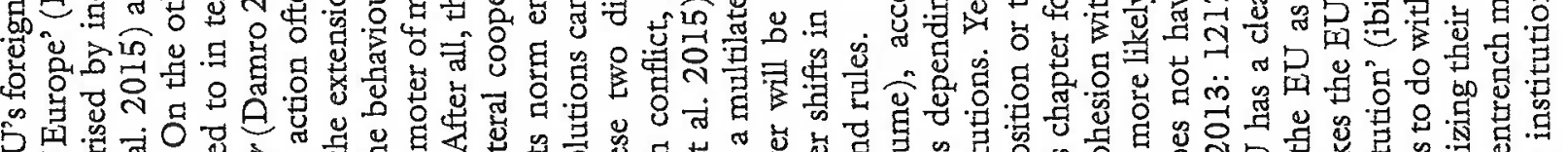

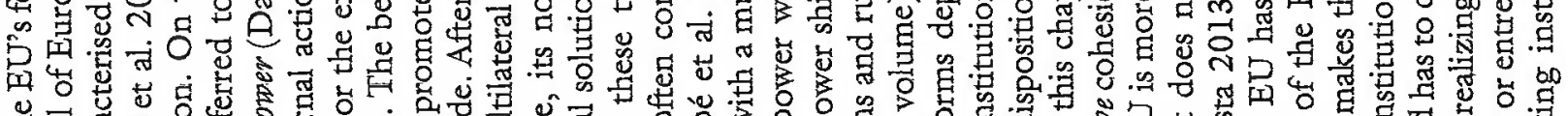

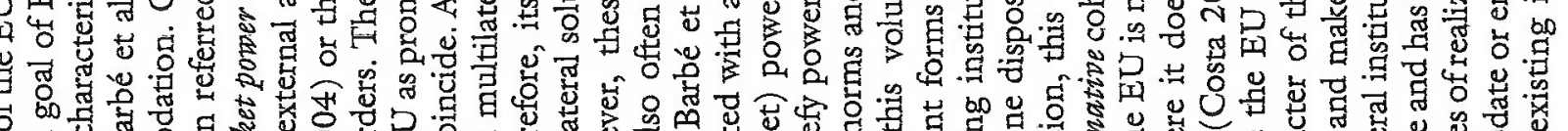

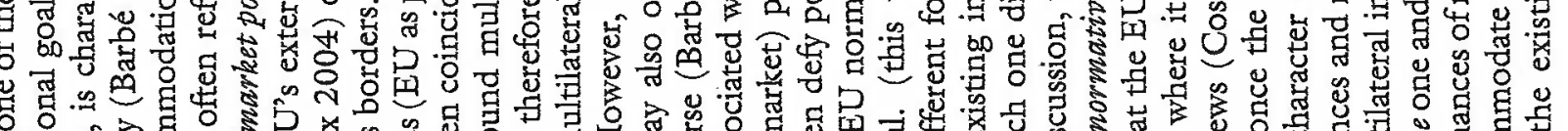

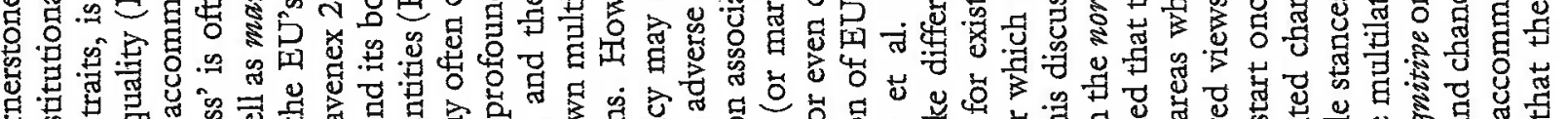

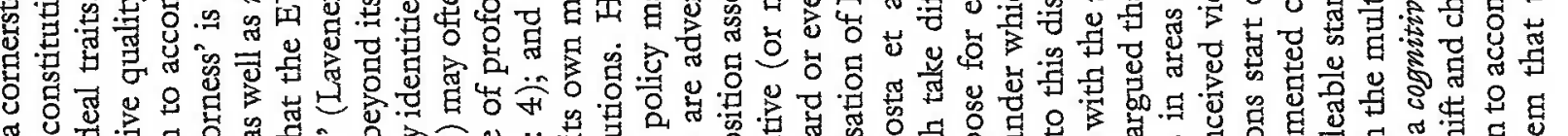
.

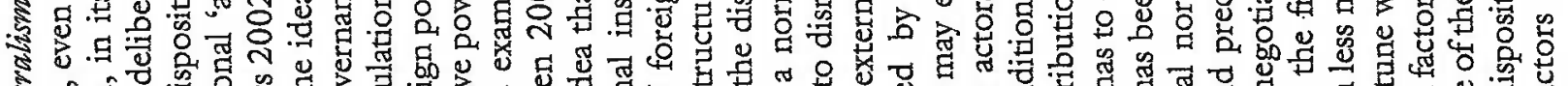

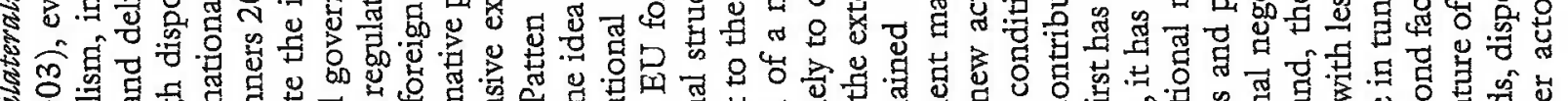

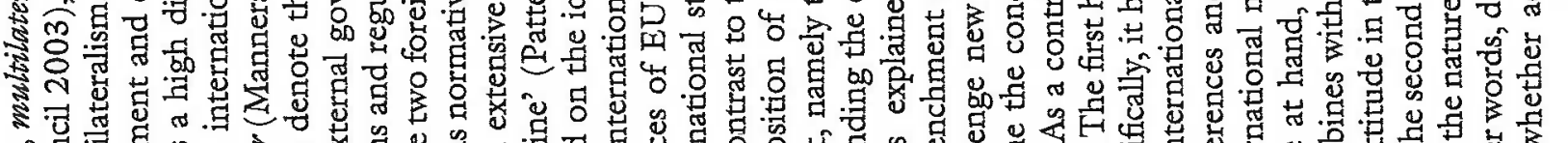

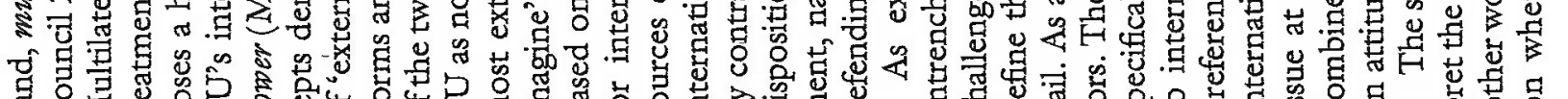

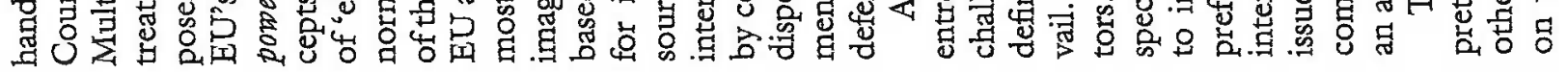

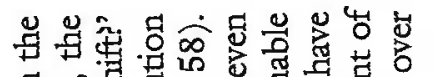

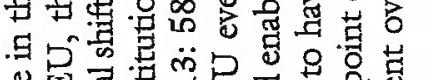

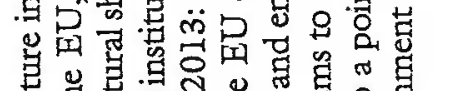

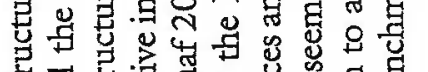

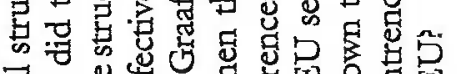

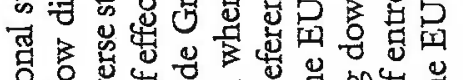

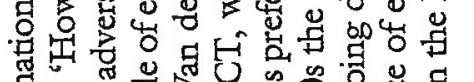

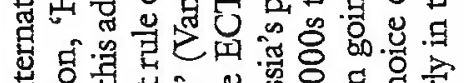

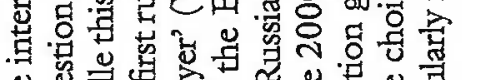

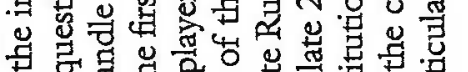

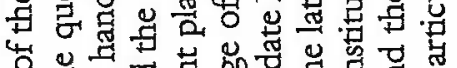

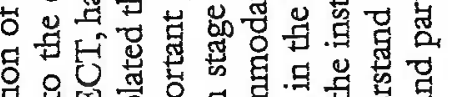

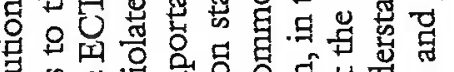

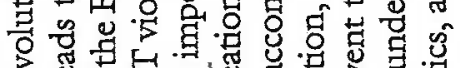

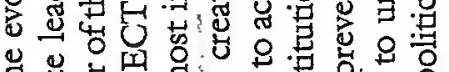

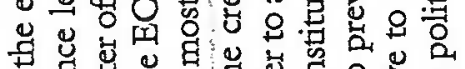

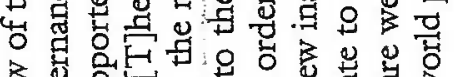

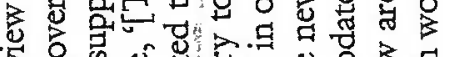

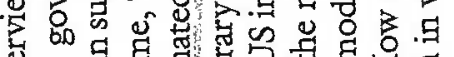

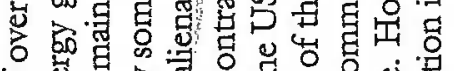

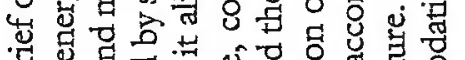

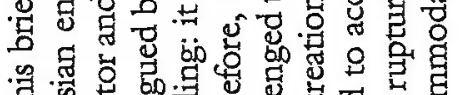

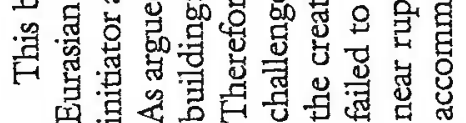

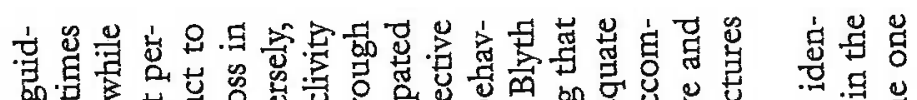

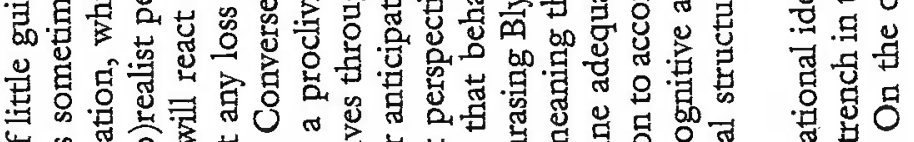

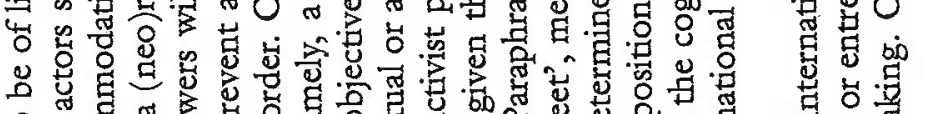

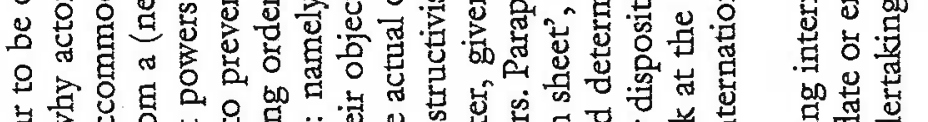

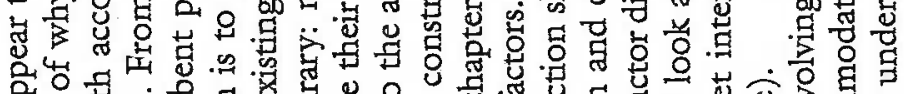

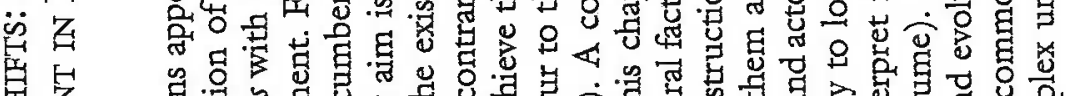

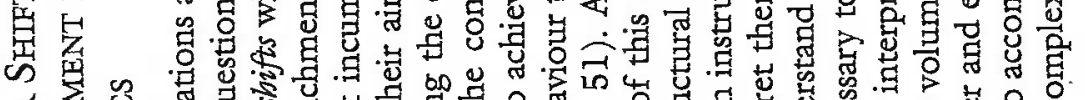

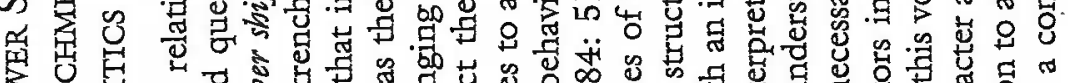

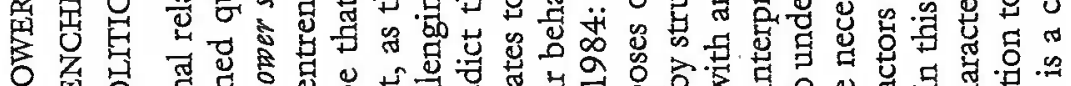

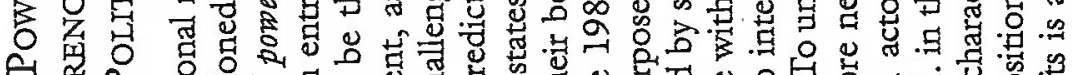

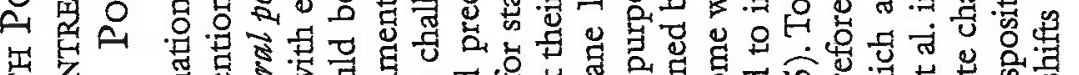

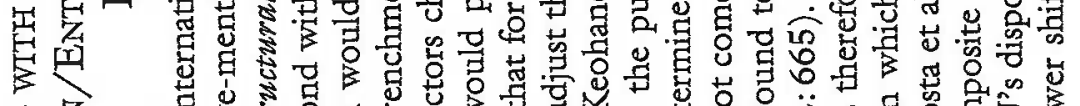

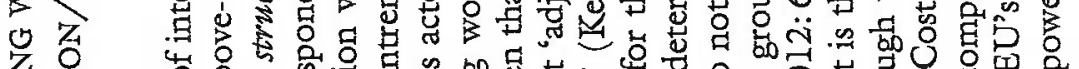

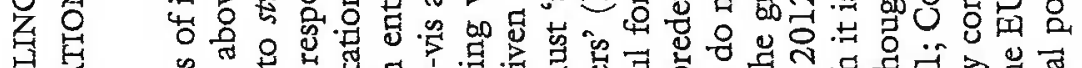

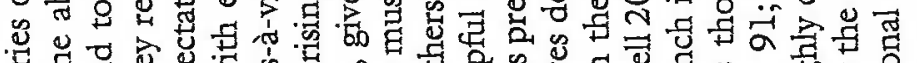

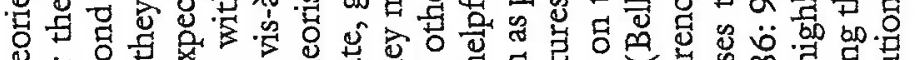

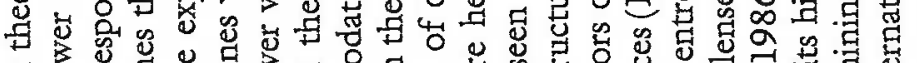

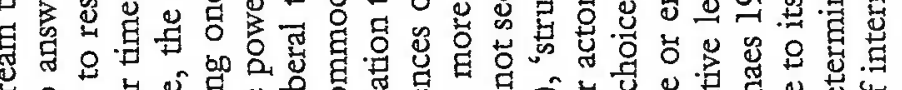

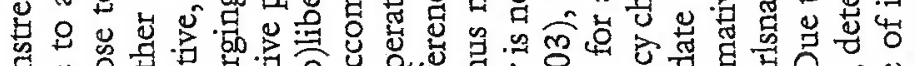

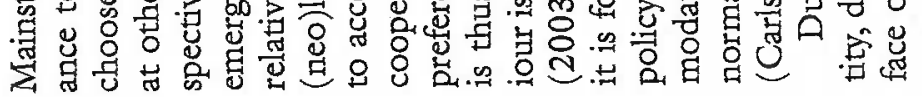



品品

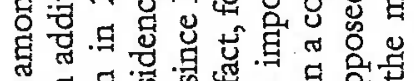

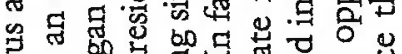

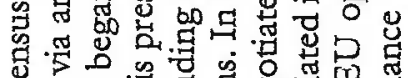

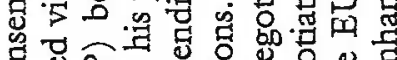

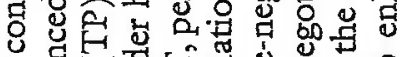
त

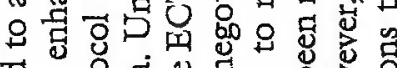
尊造.

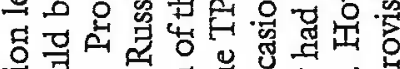

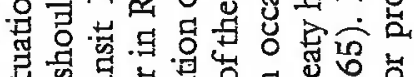

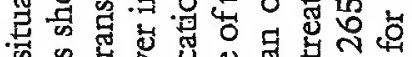

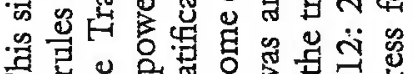

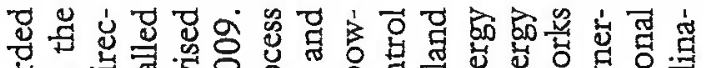

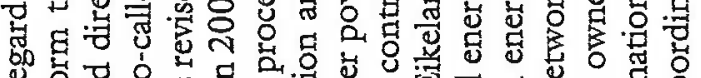

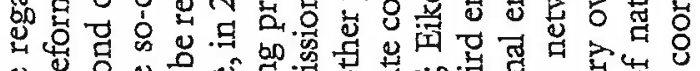

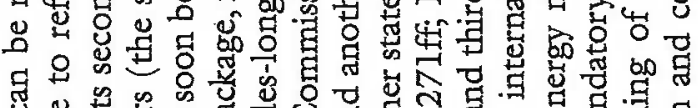

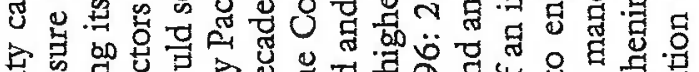

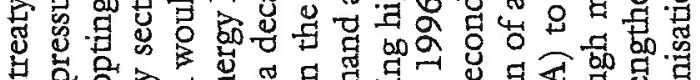

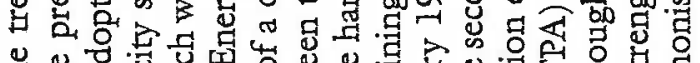

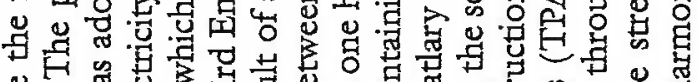

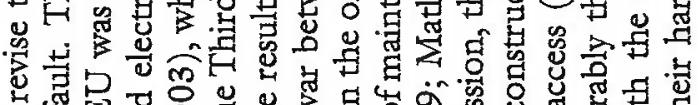

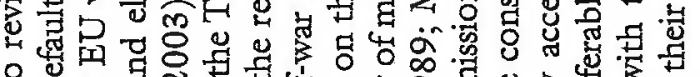

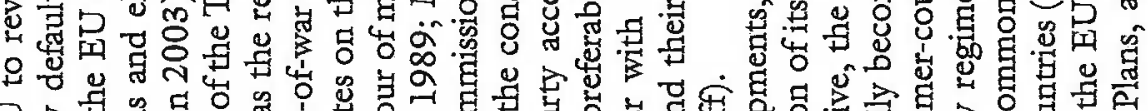

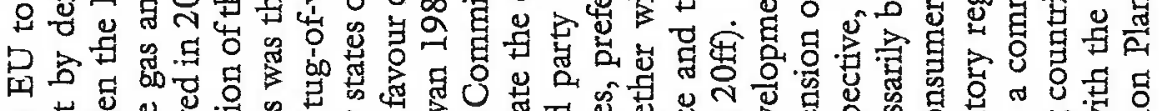

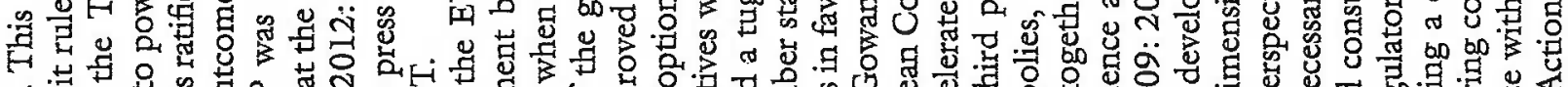

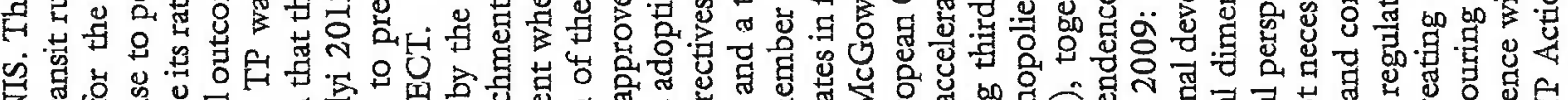

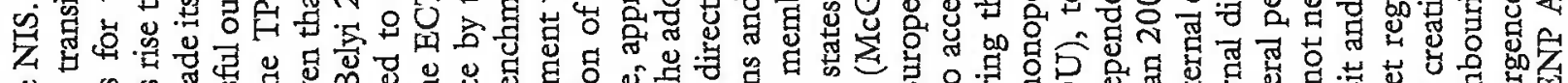

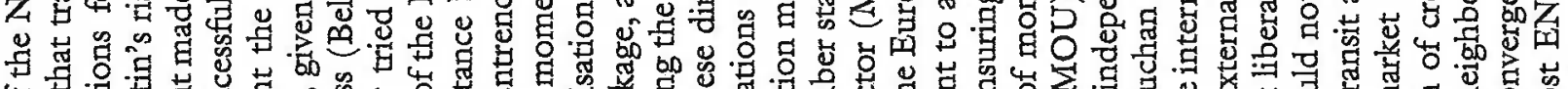

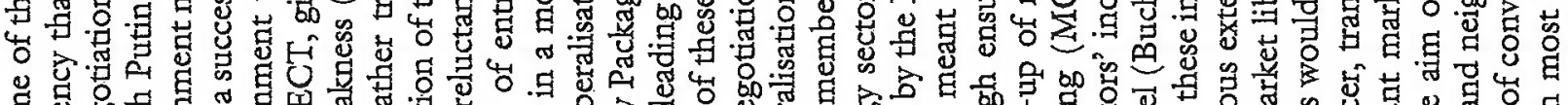

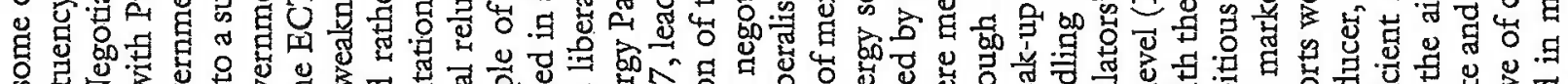

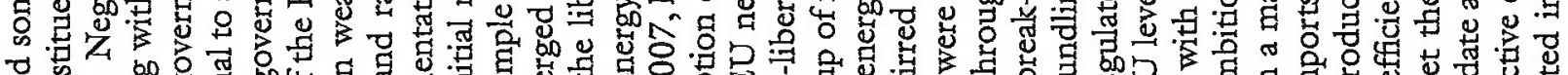

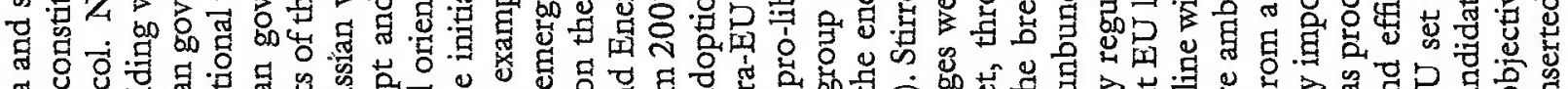

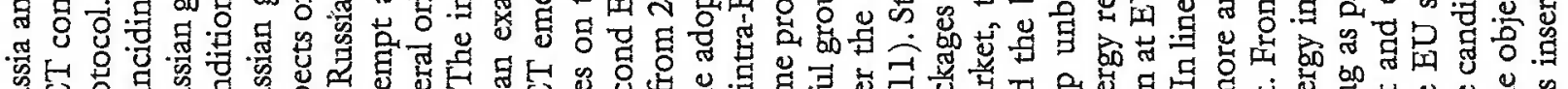

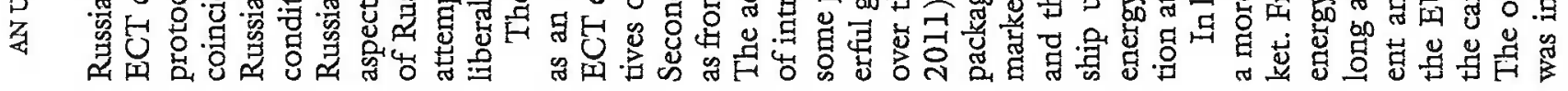

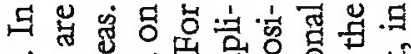

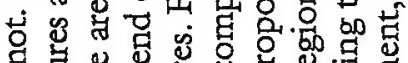

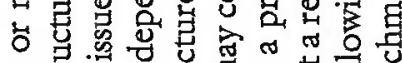

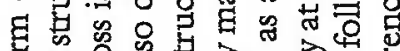

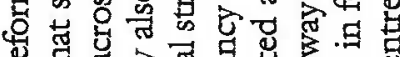

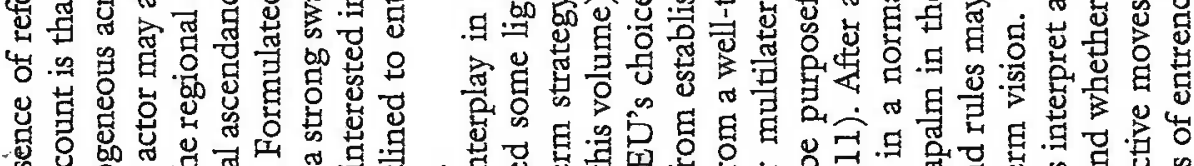

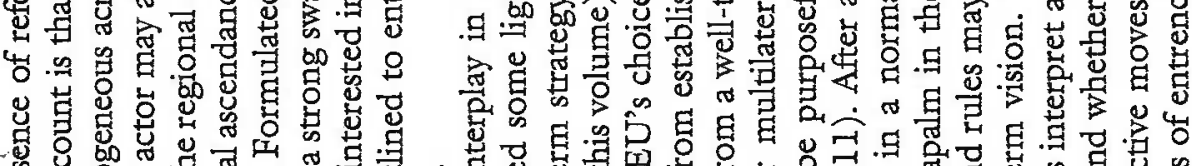

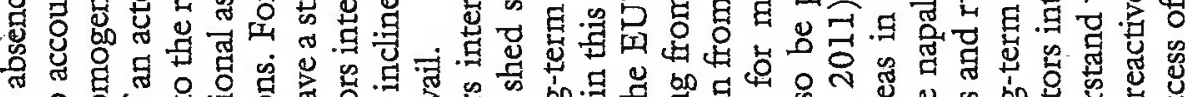
웅

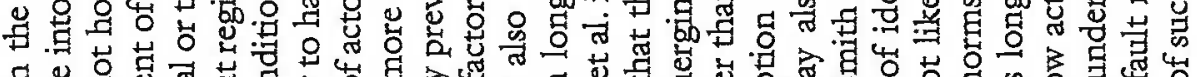

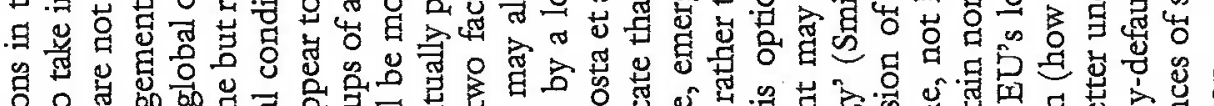

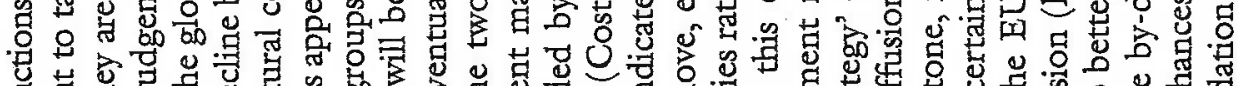

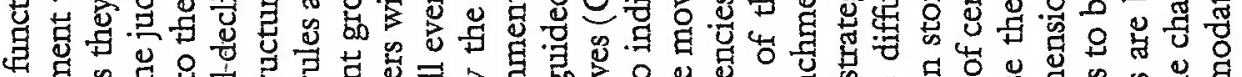

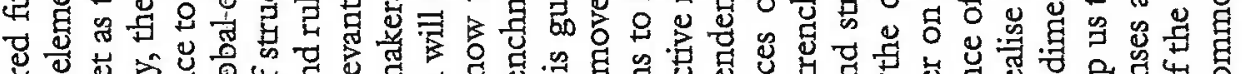

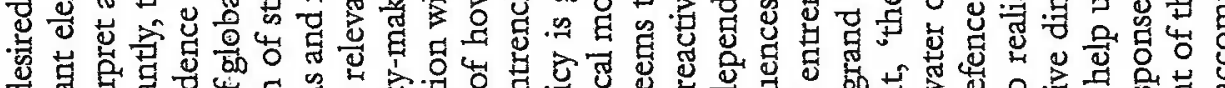

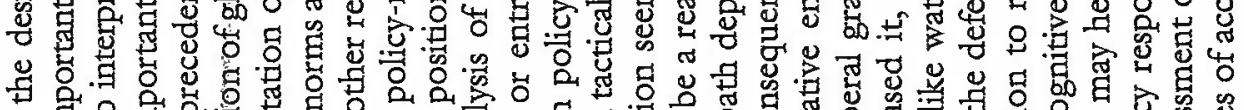

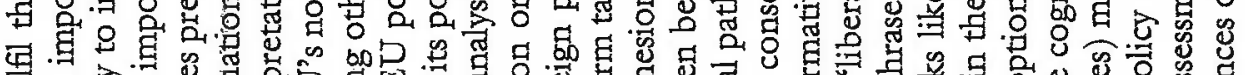

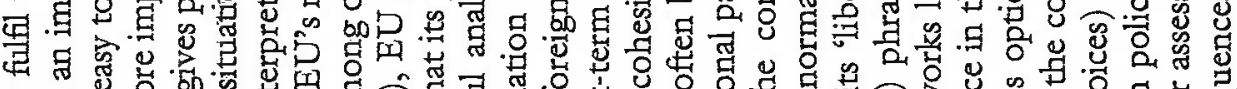

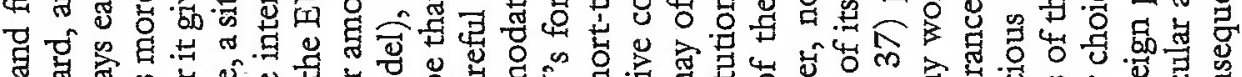

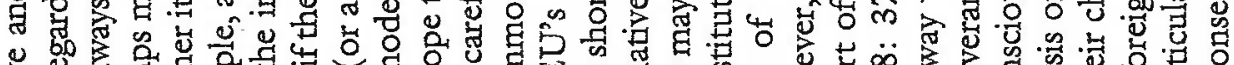

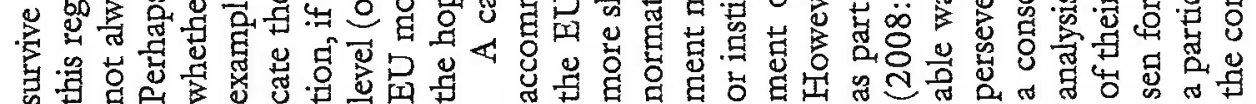

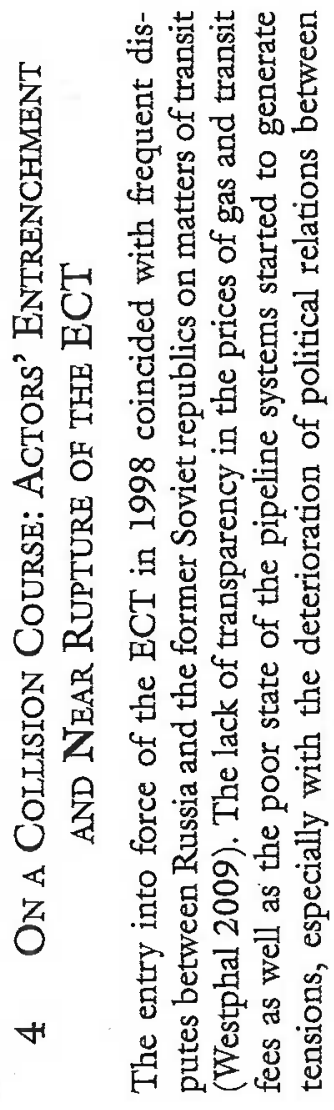




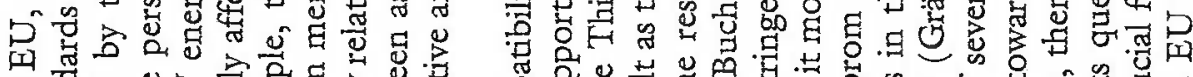

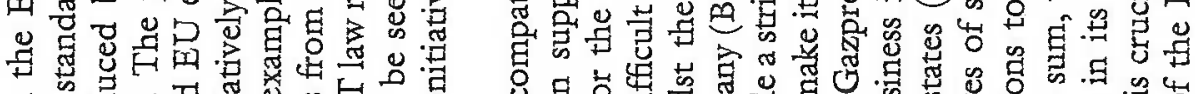

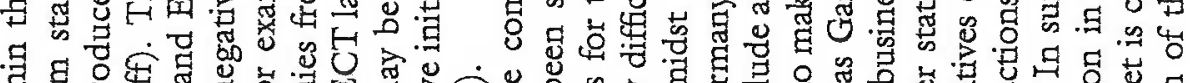

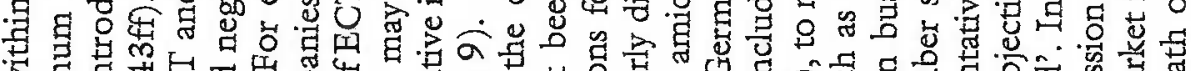

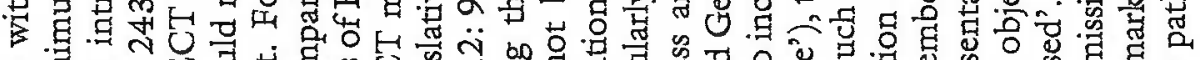

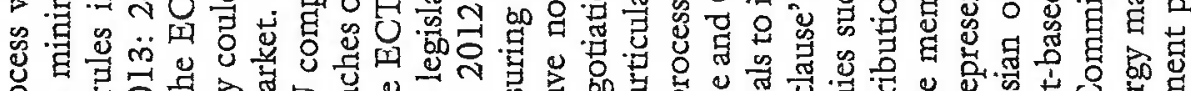

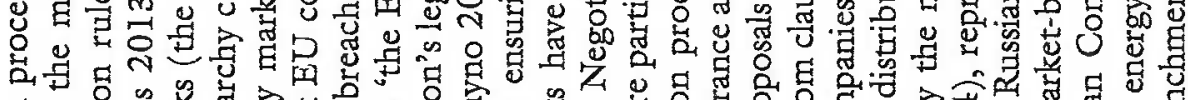

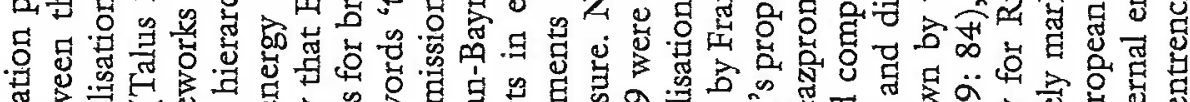

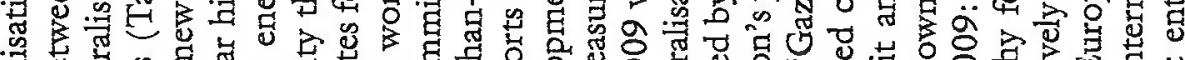

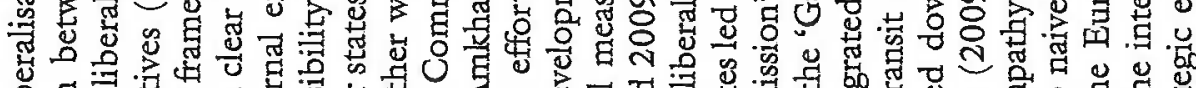

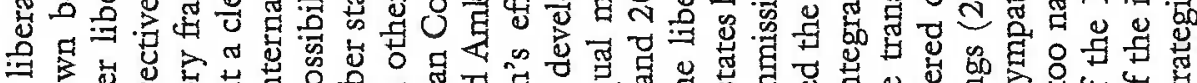

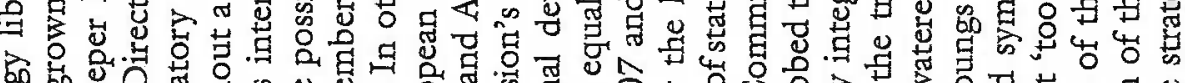

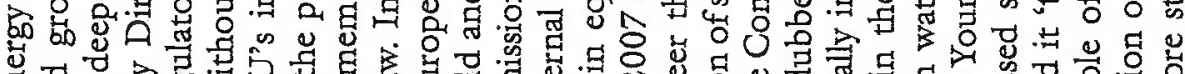

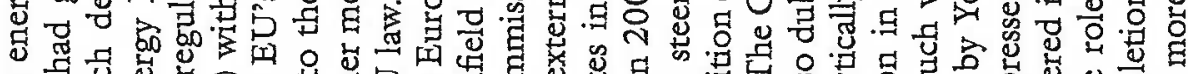

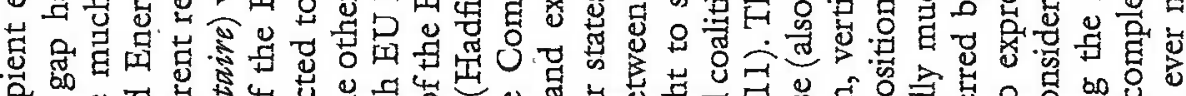

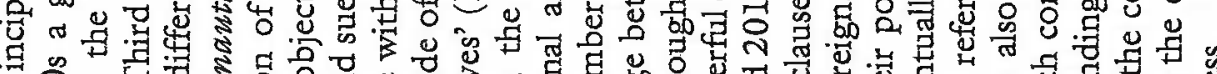

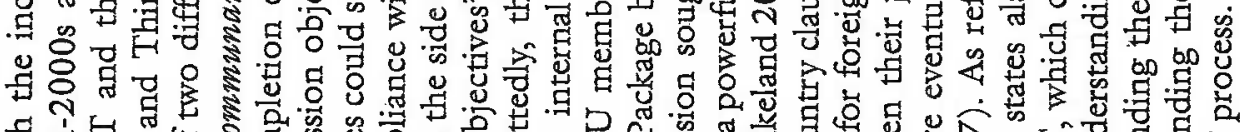

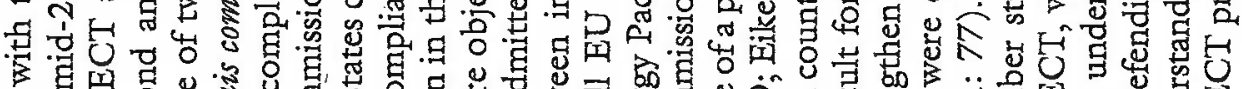

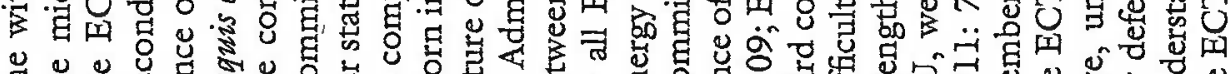

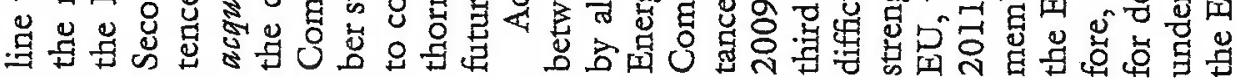

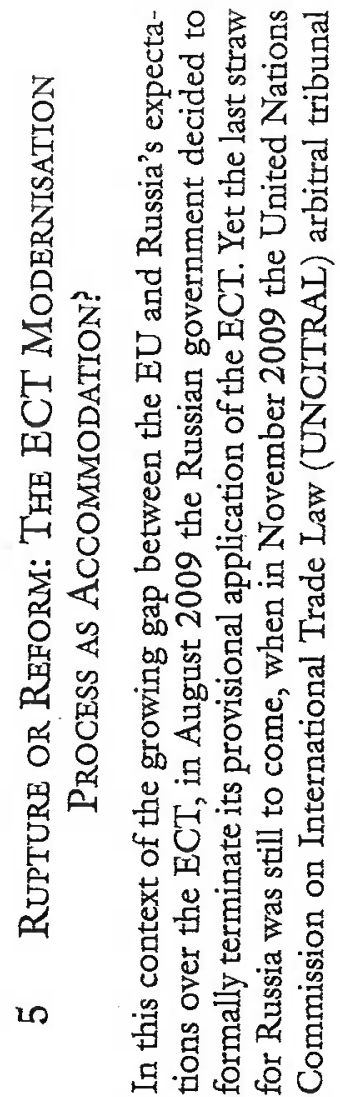

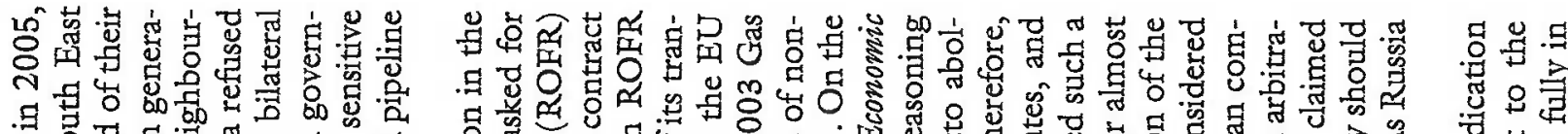

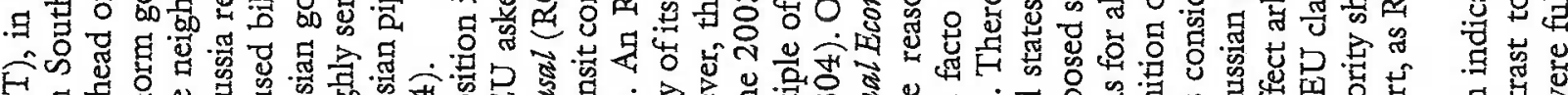

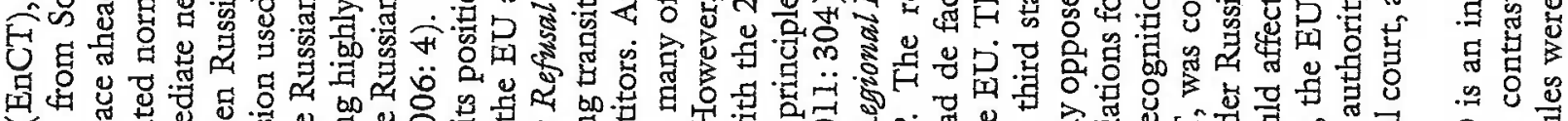

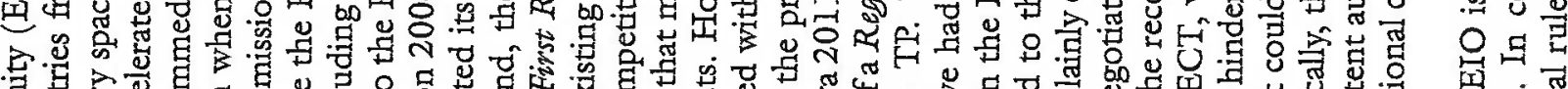

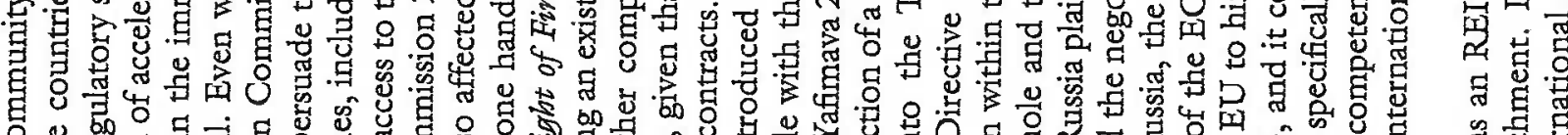

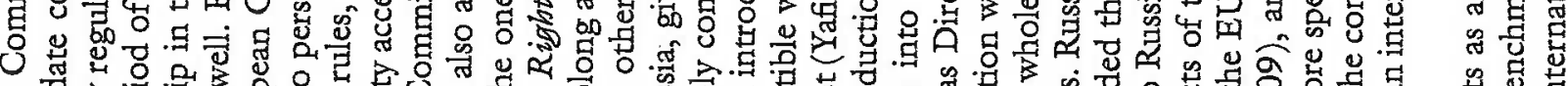

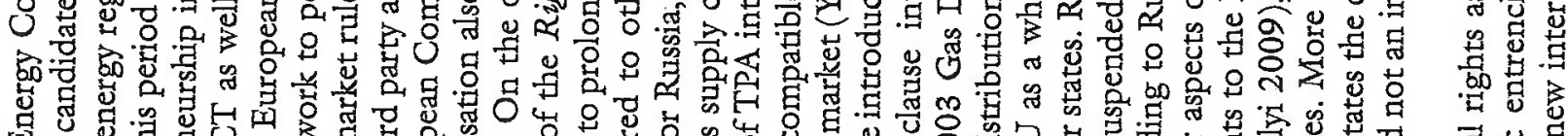

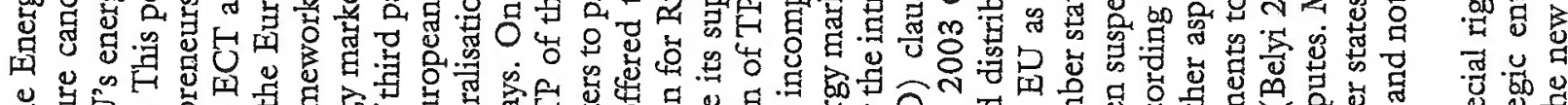

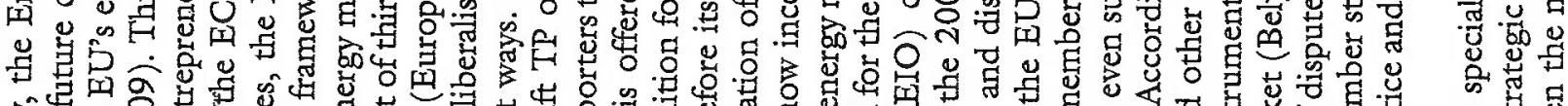

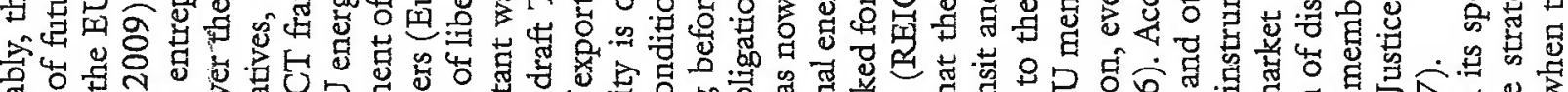

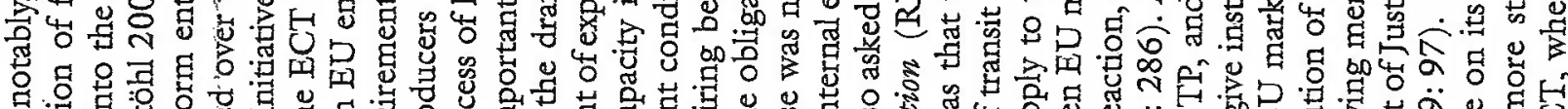

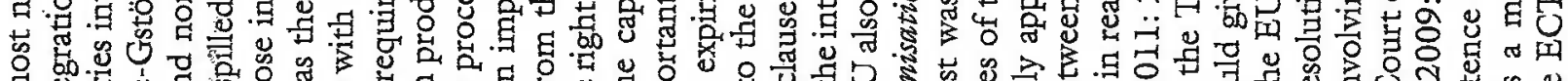

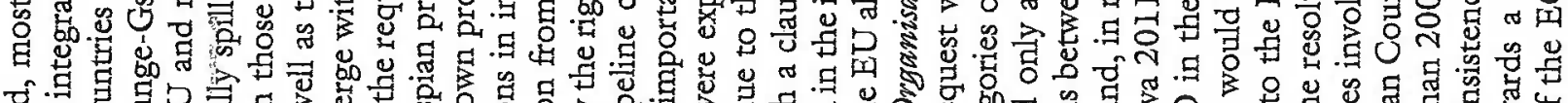

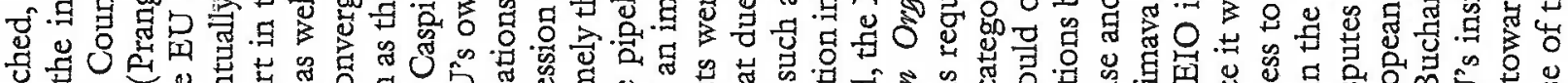

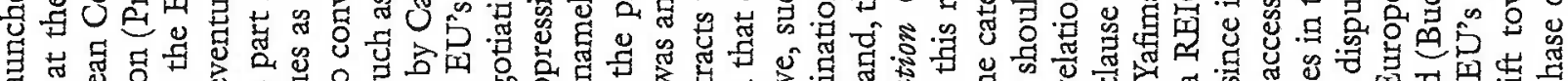

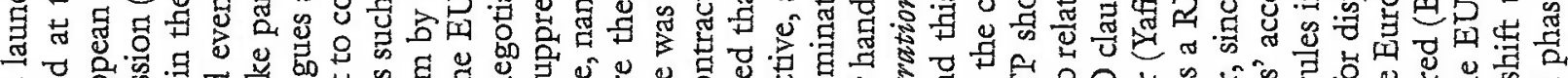

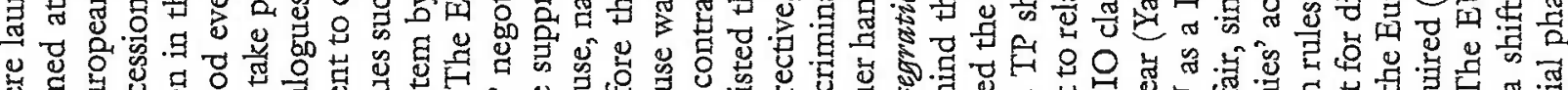

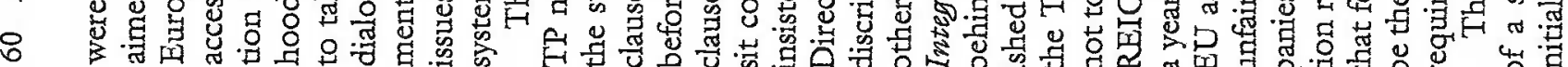




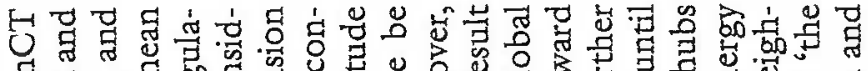

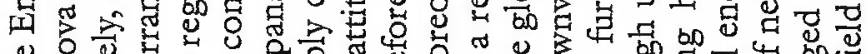

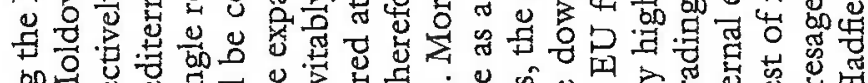

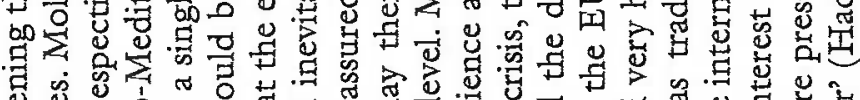

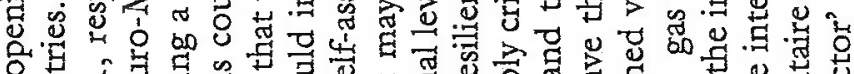

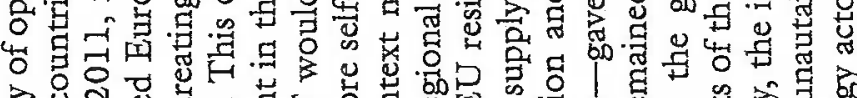

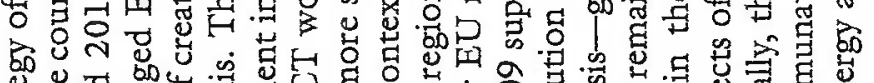

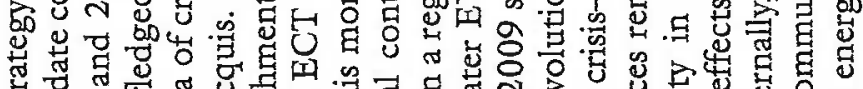

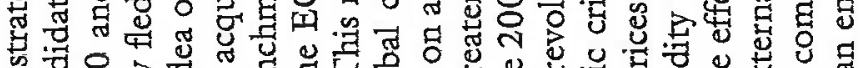

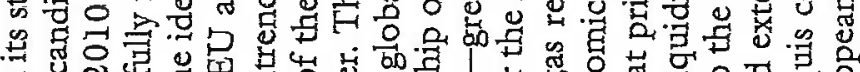

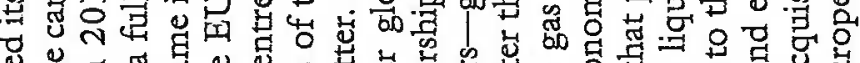

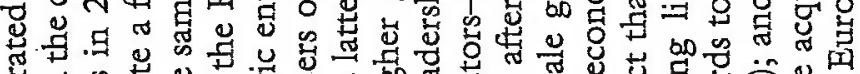

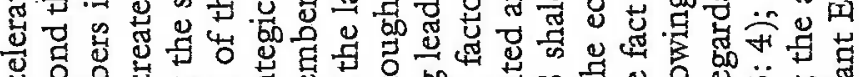

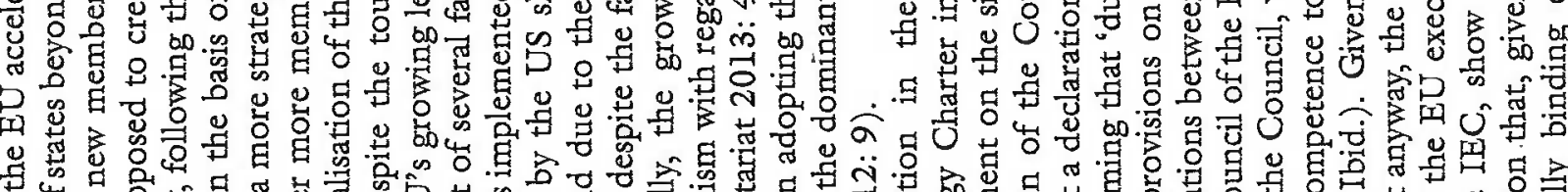

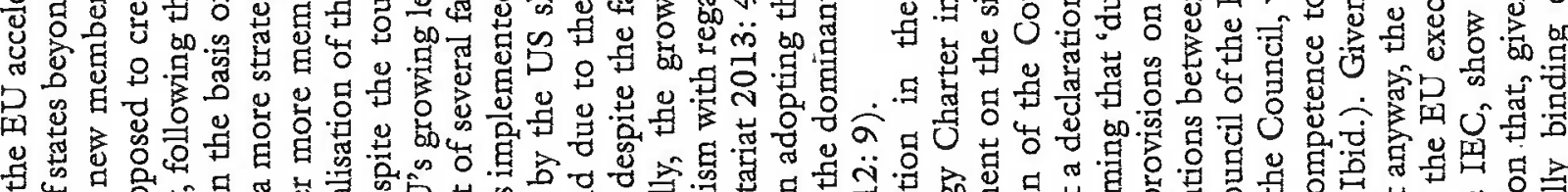

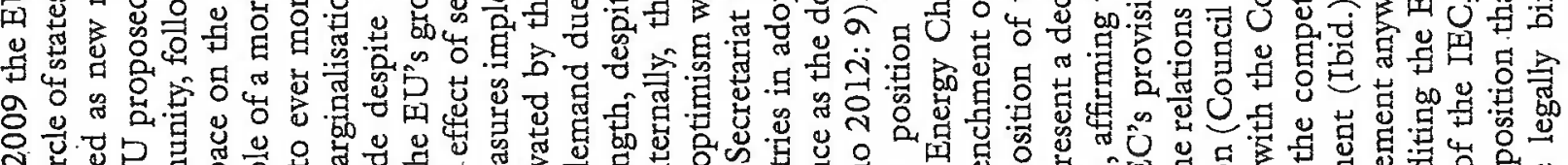

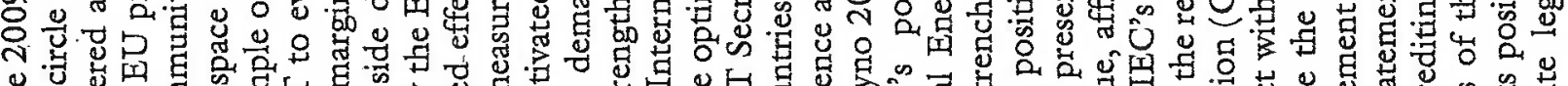

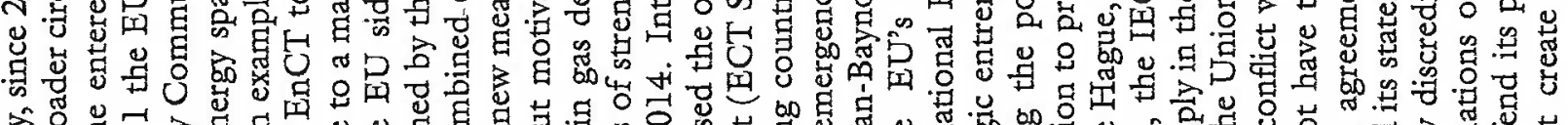

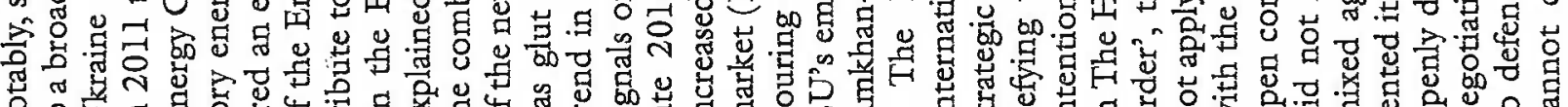

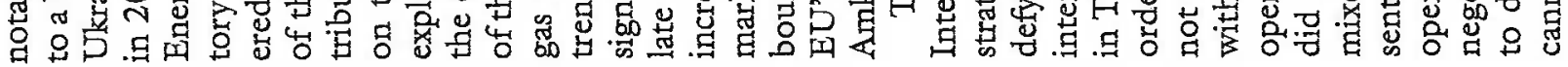

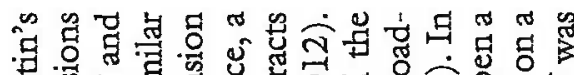

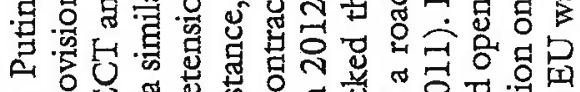

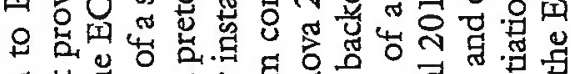

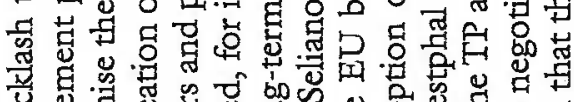

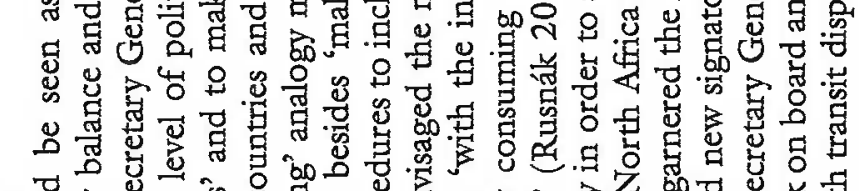

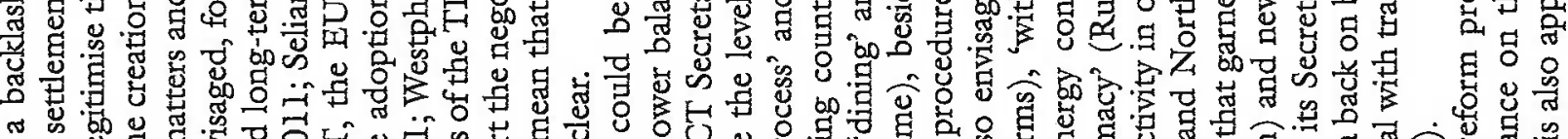
๙

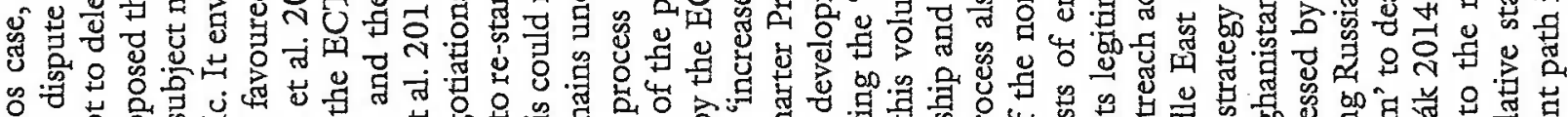

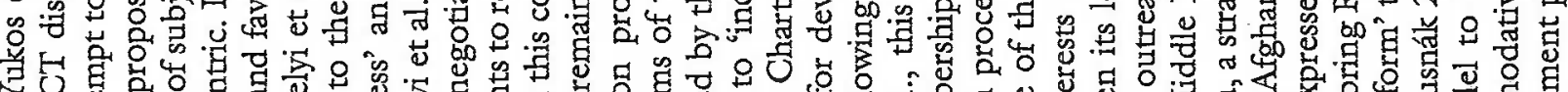

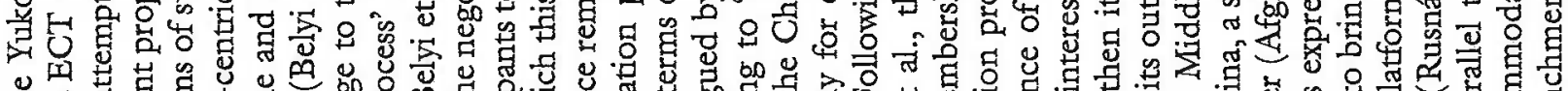

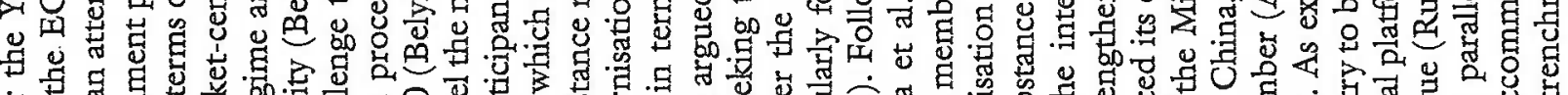

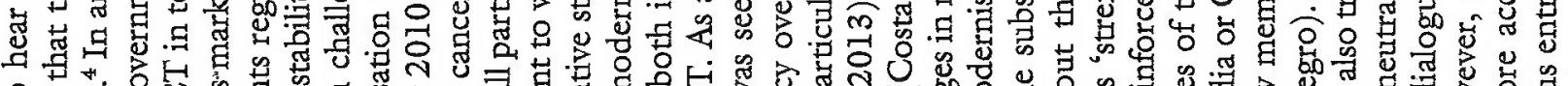
\&

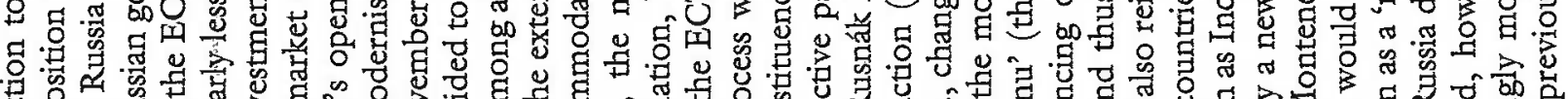

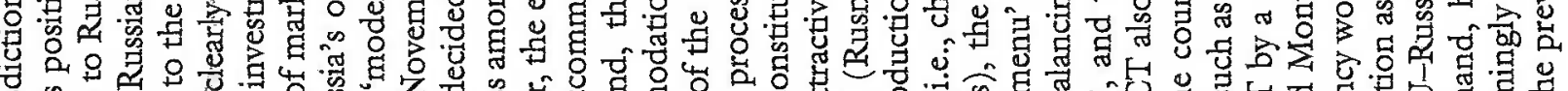

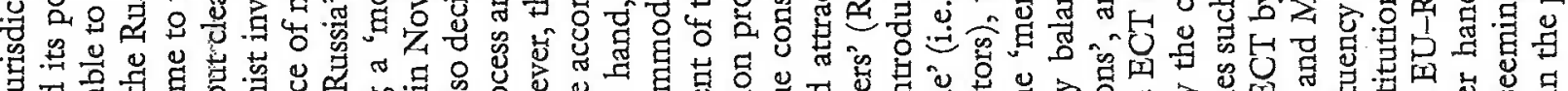

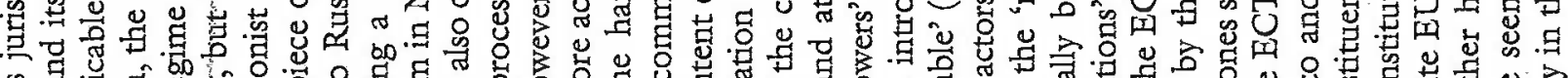

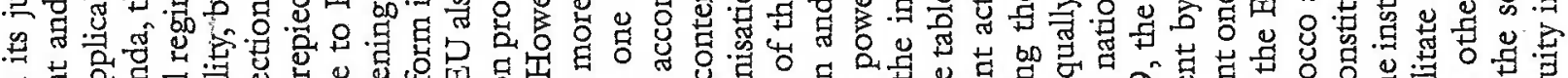

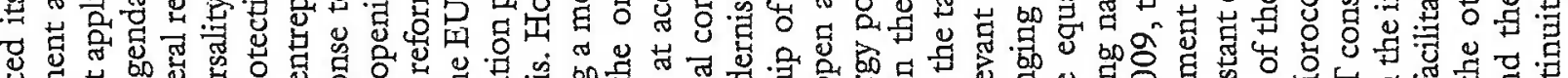

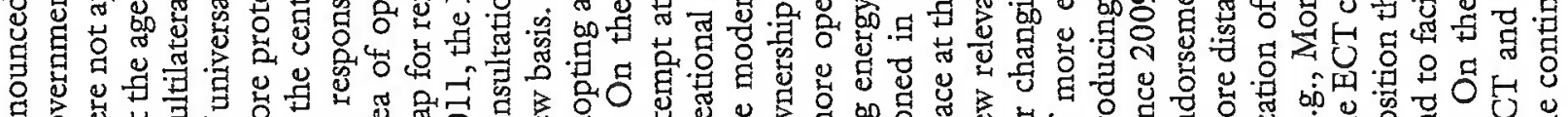

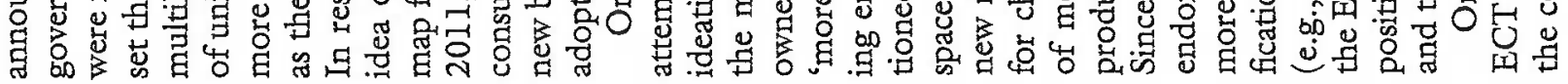




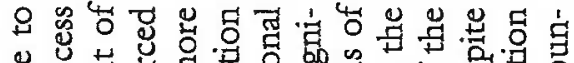

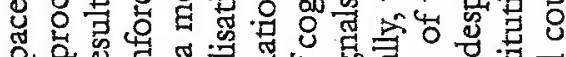

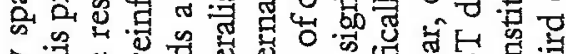

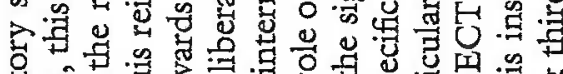

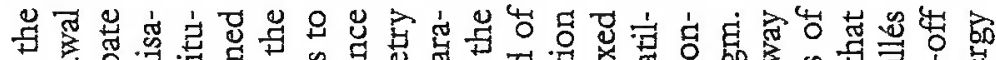

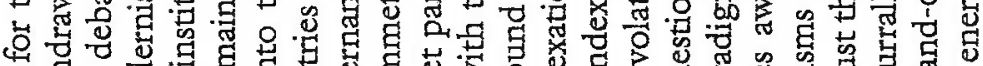

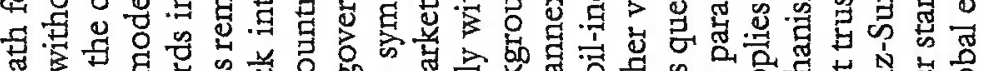

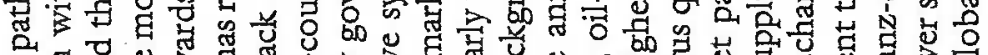

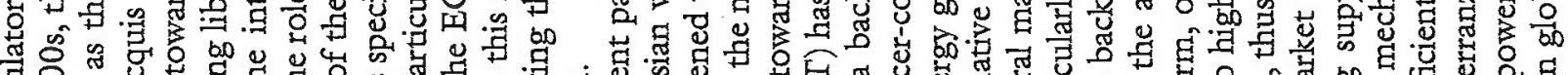
鿒务

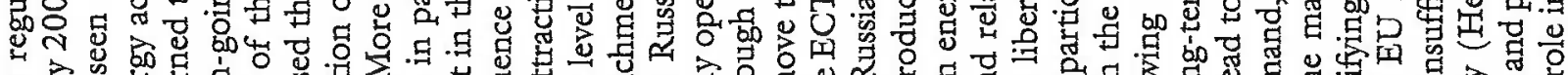

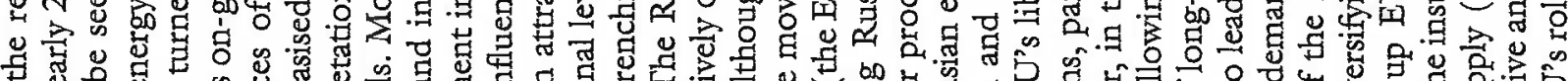

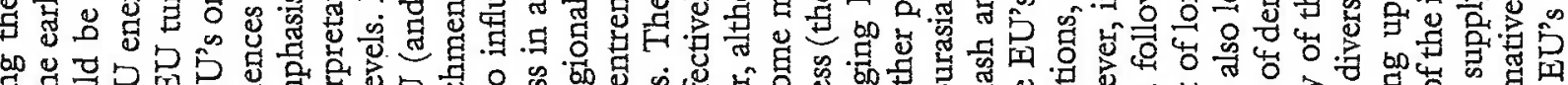

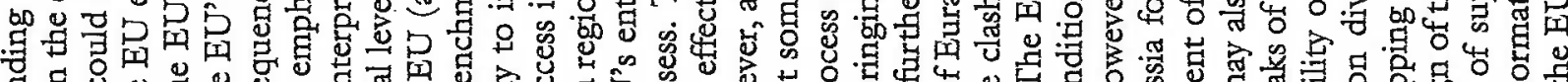

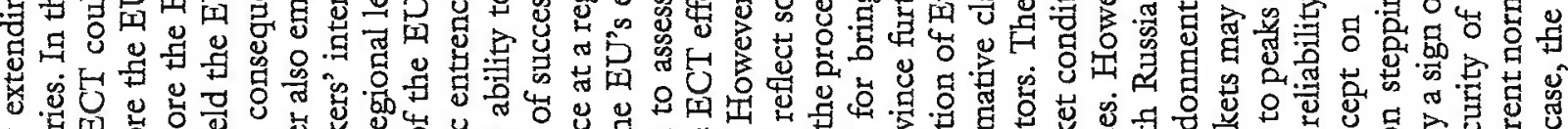

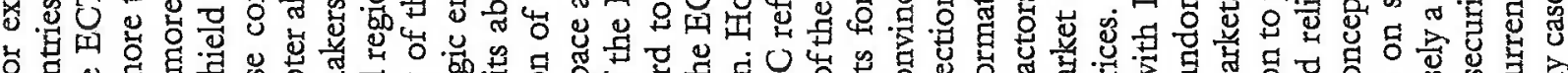

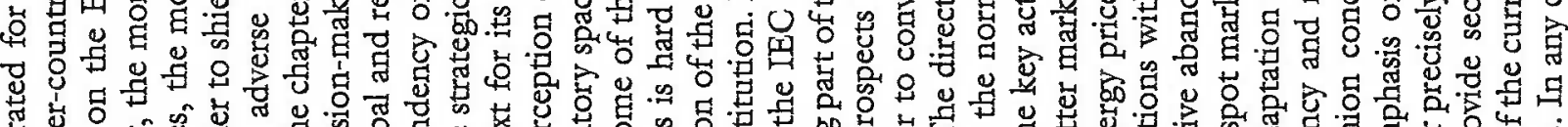

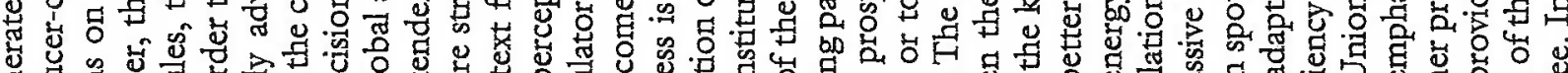

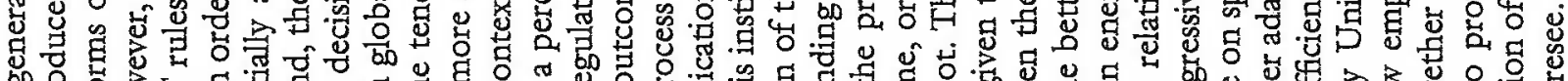

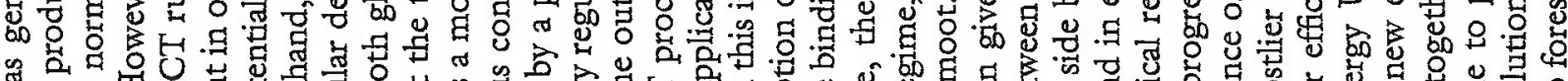

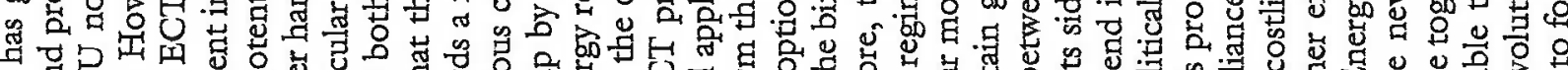

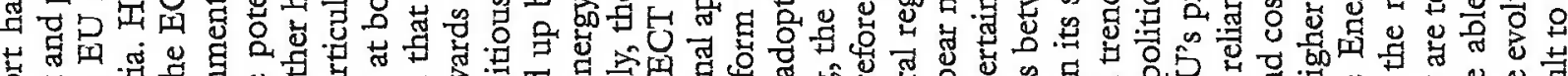

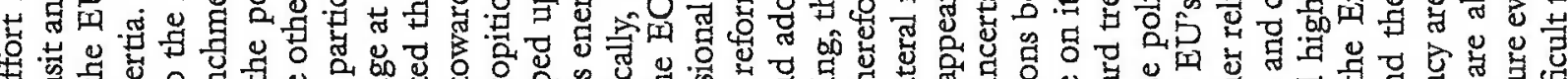

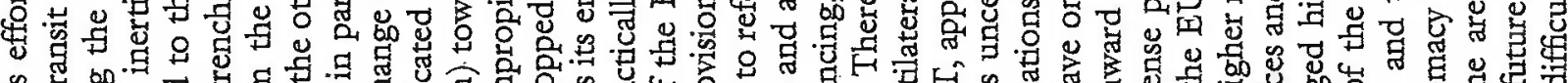

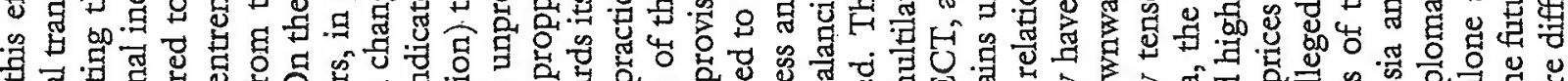

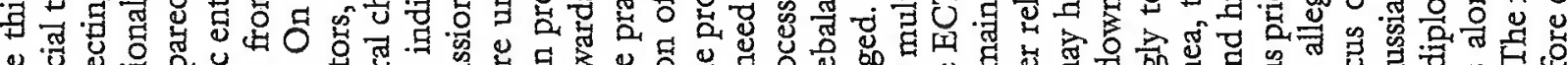

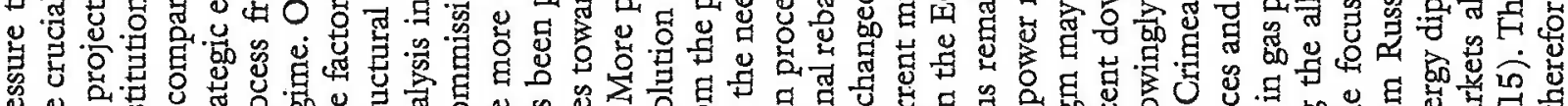

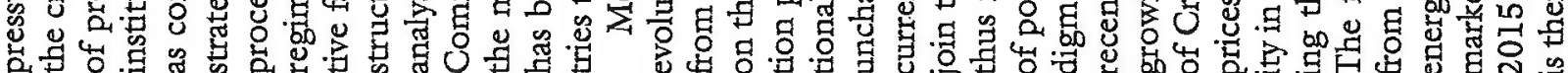

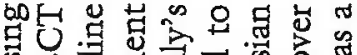

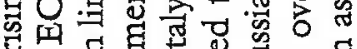

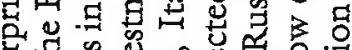

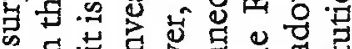

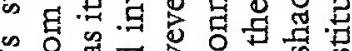

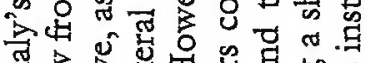

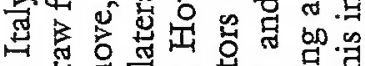

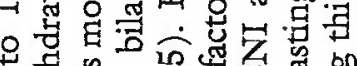

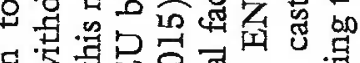

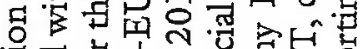

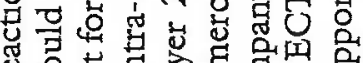

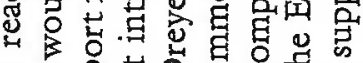

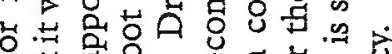

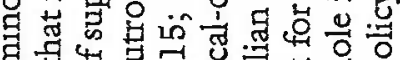

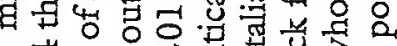

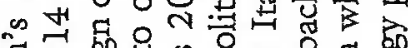

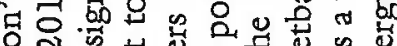

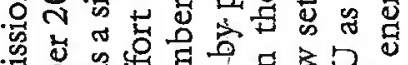

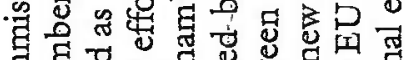

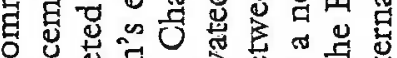

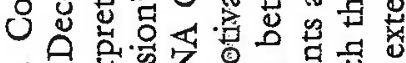

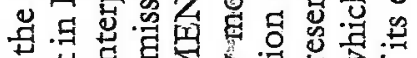

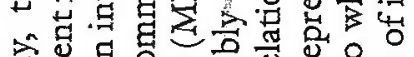

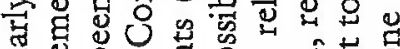

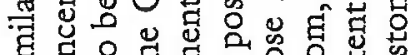

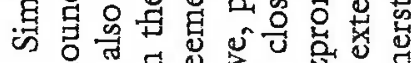

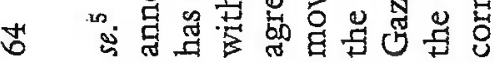

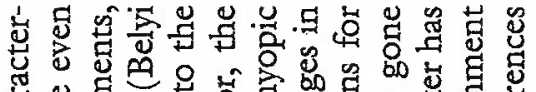

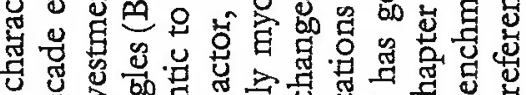

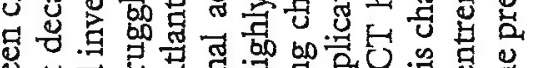

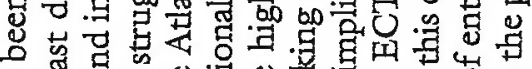

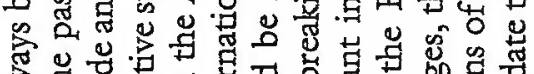

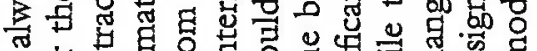

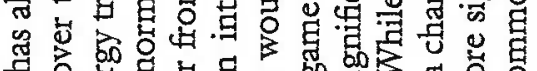

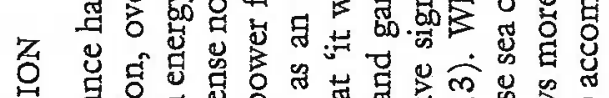

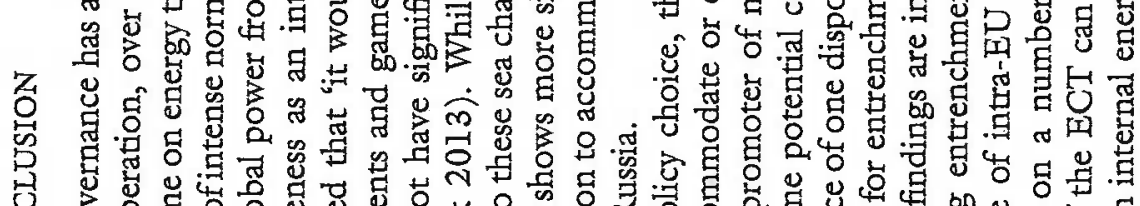

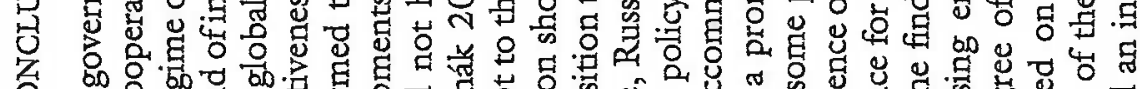

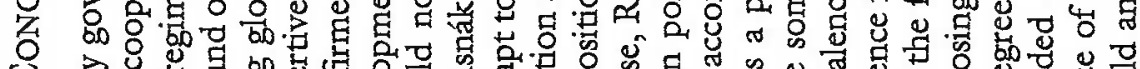

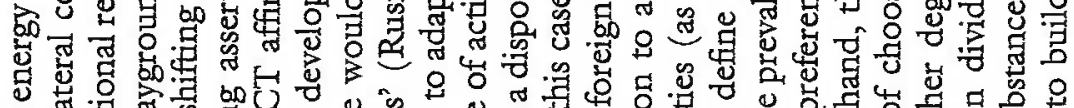

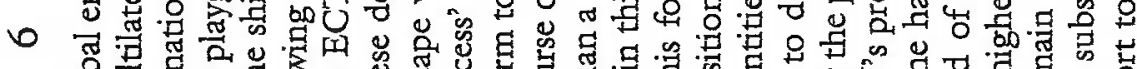

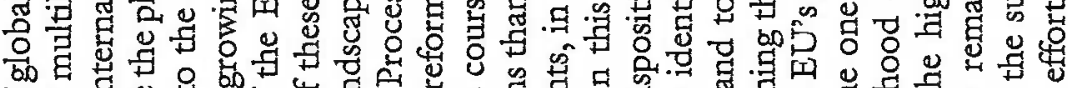

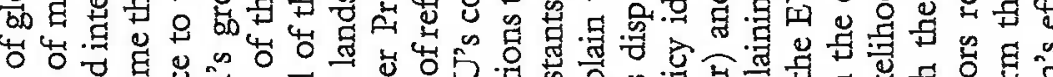

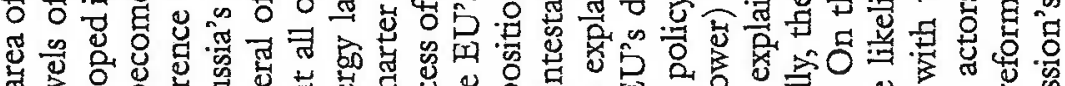

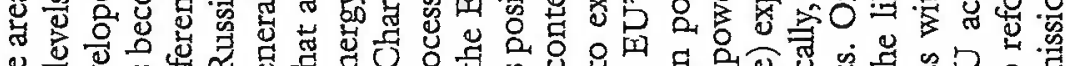

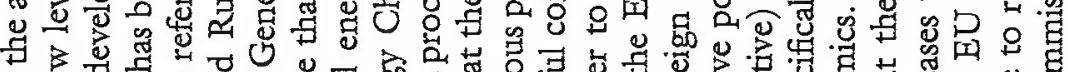

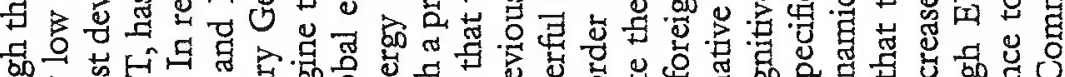

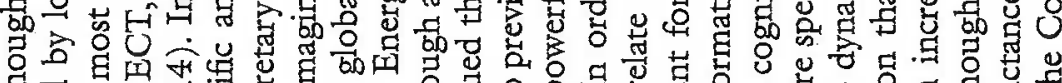

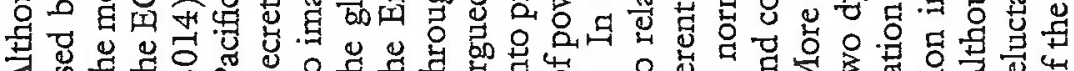

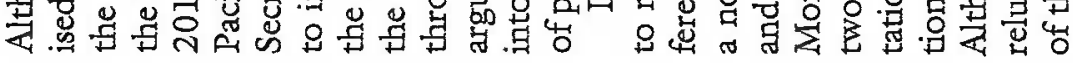




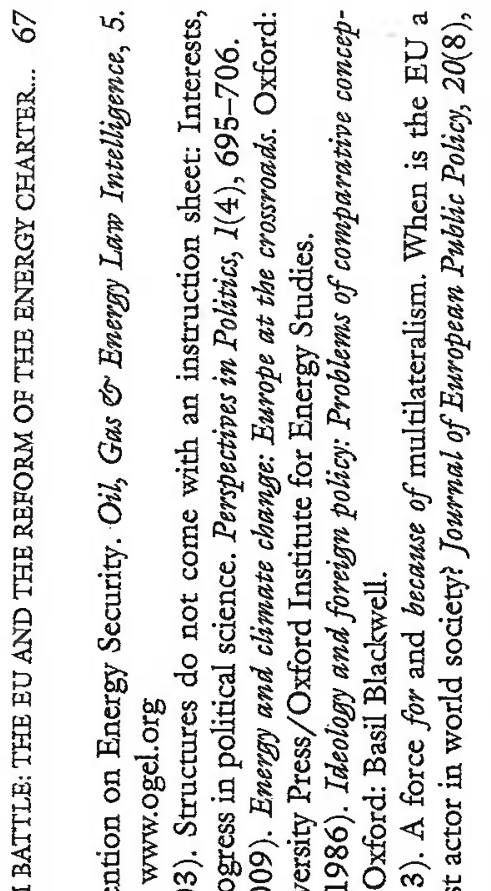

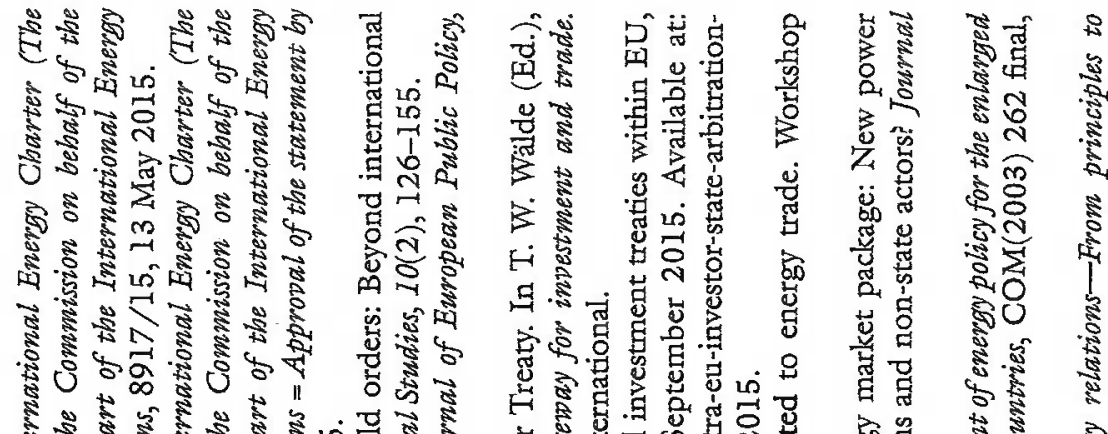
है कै

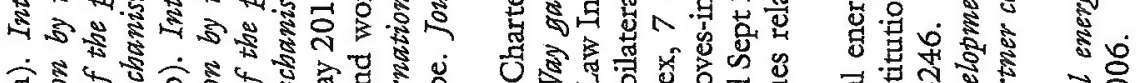

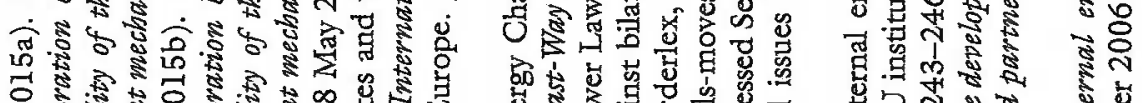

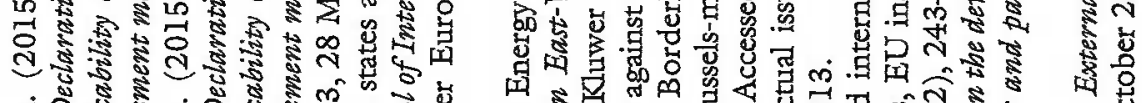
मं

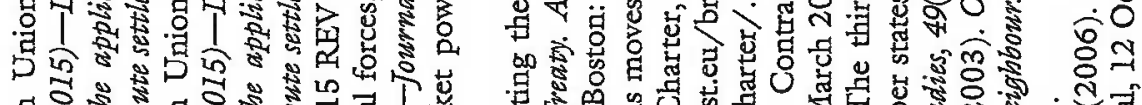

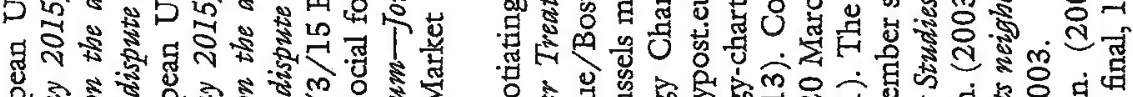
边

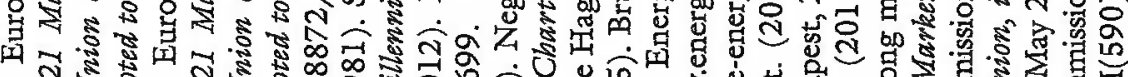

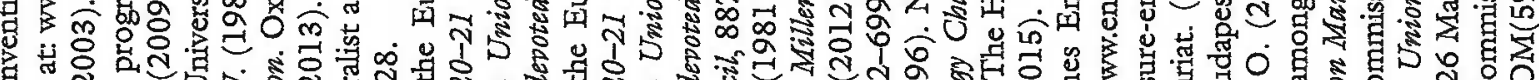

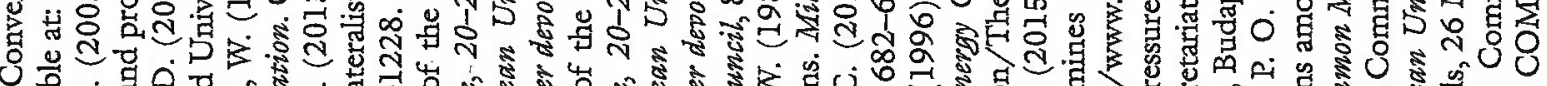

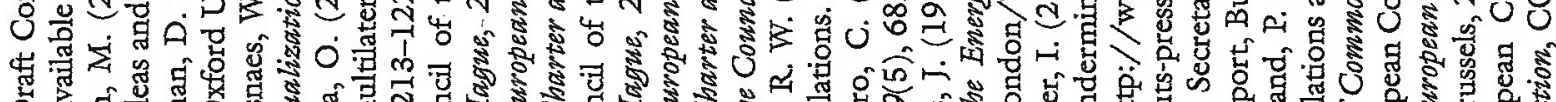

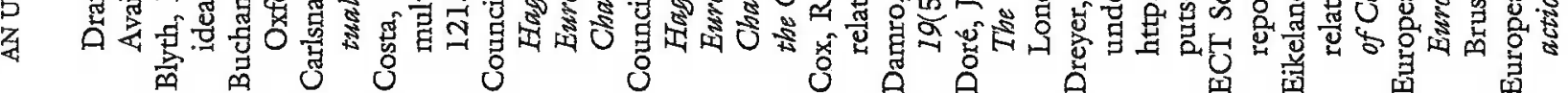

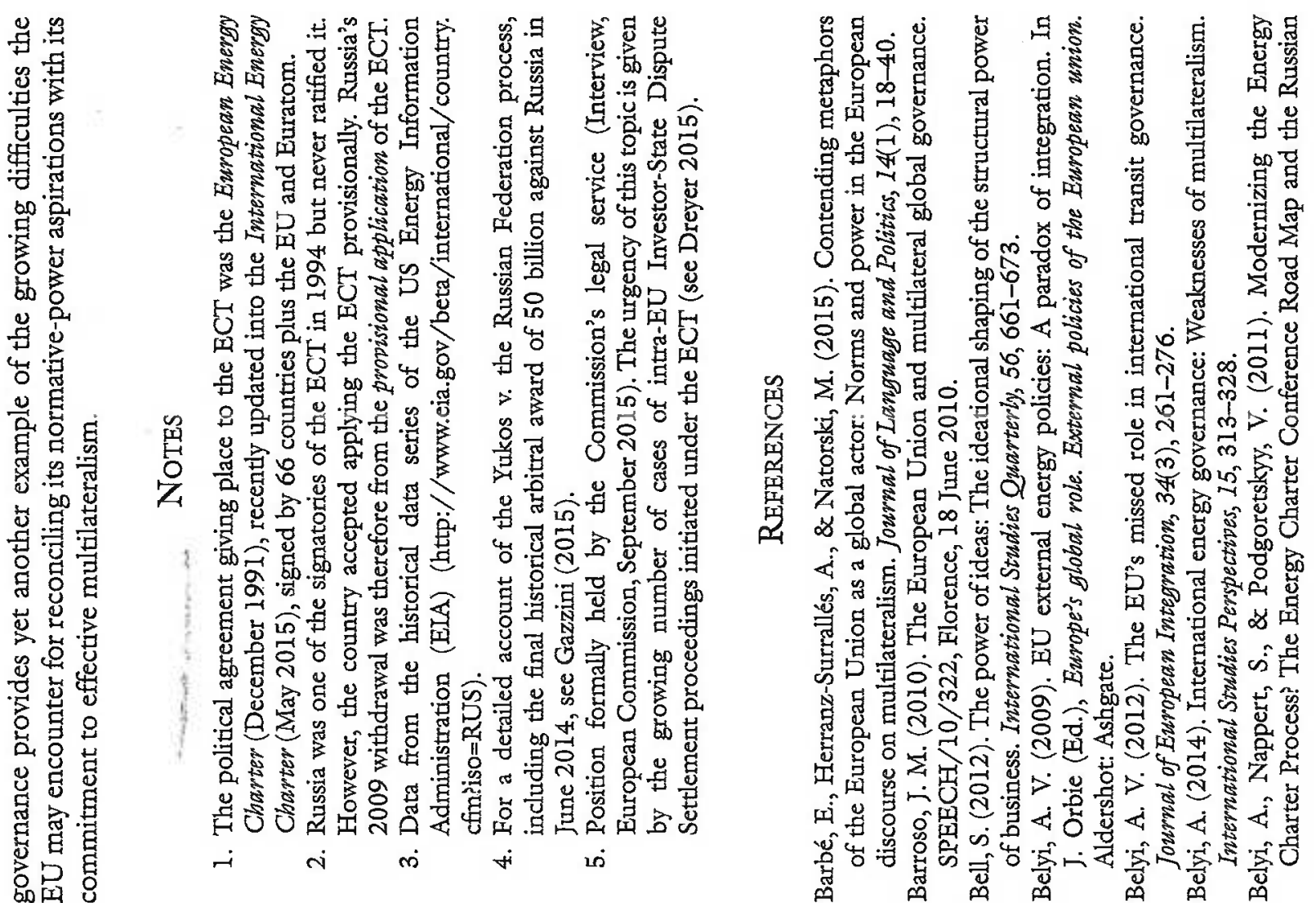




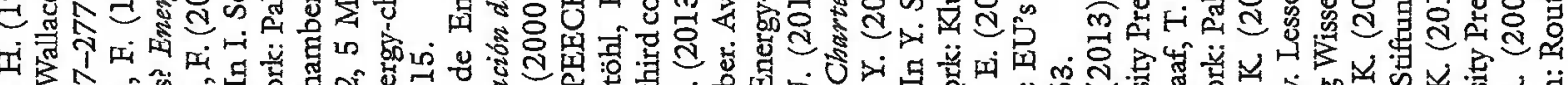

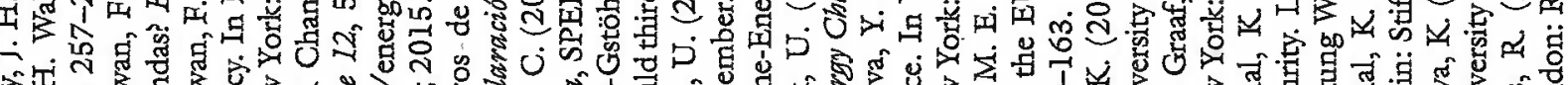

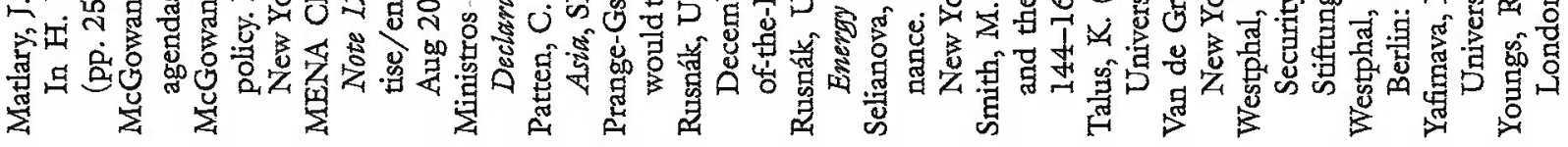

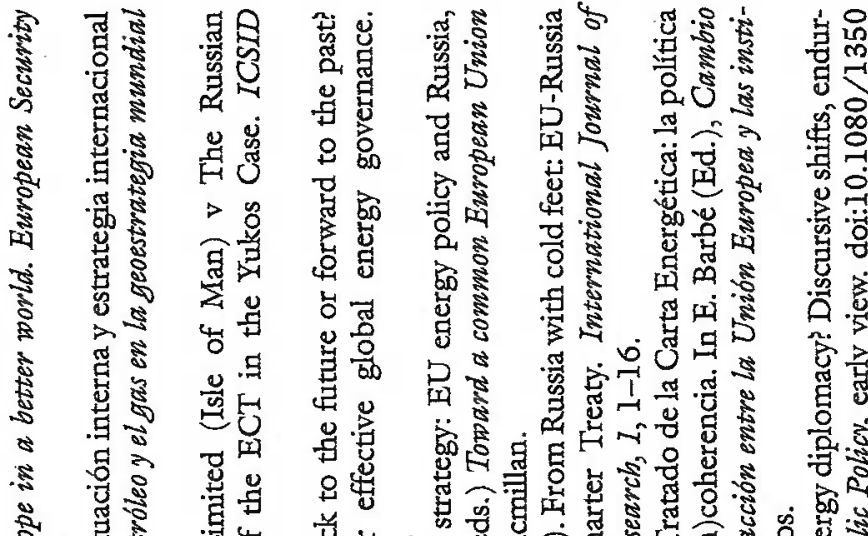

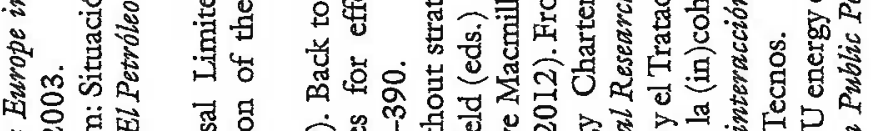

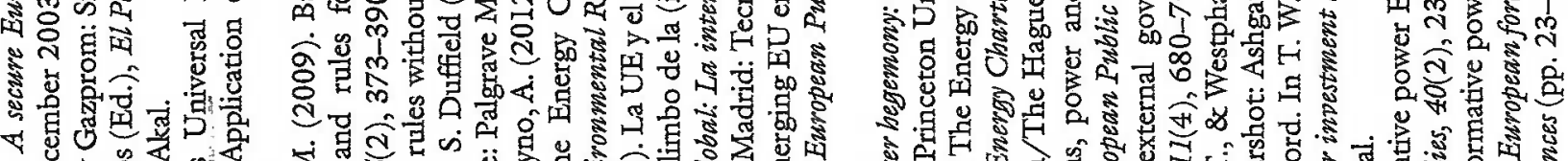

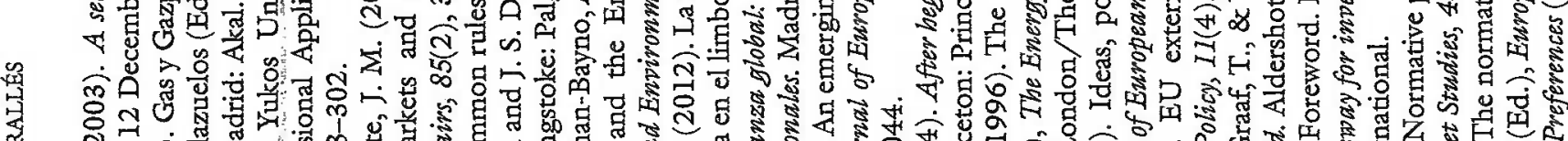

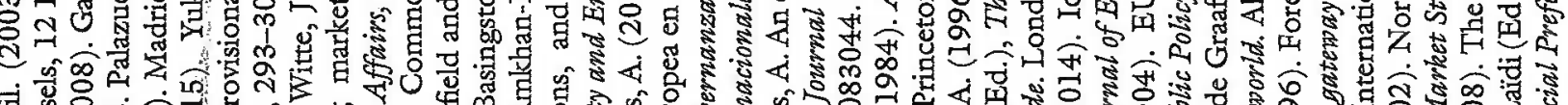
चं

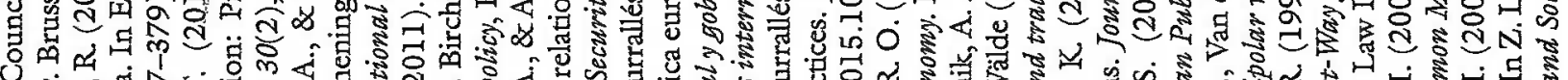

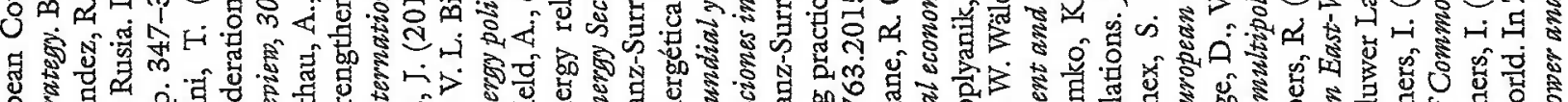

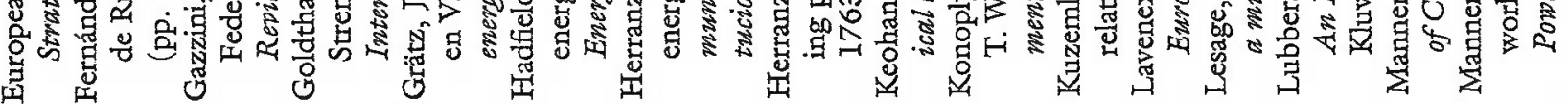

